\title{
Connexins: Synthesis, Post-Translational Modifications, and Trafficking in Health and Disease
}

\author{
Trond Aasen ${ }^{1, *(\mathbb{D})}$, Scott Johnstone ${ }^{2,3, *(\mathbb{D})}$, Laia Vidal-Brime ${ }^{1}$, K. Sabrina Lynn ${ }^{4}$ \\ and Michael Koval $4,5, *$ (D) \\ 1 Translational Molecular Pathology, Vall d'Hebron Institute of Research (VHIR), \\ Autonomous University of Barcelona, CIBERONC, 08035 Barcelona, Spain; laia.vidal.b@gmail.com \\ 2 Robert M. Berne Cardiovascular Research Center, University of Virginia School of Medicine, P.O. Box 801394, \\ Charlottesville, VI 22908, USA \\ 3 Institute of Cardiovascular and Medical Sciences, College of Medical, Veterinary and Life Sciences, \\ University of Glasgow, Glasgow G12 8TT, UK \\ 4 Division of Pulmonary, Allergy, Critical Care and Sleep Medicine, Department of Medicine, \\ Emory University School of Medicine, Atlanta, GA 30322, USA; k.s.lynn@emory.edu \\ 5 Department of Cell Biology, Emory University School of Medicine, Atlanta, GA 30322, USA \\ * Correspondence: trond.aasen@vhir.org (T.A.); srj6n@virginia.edu (S.J.); mhkoval@emory.edu (M.K.); \\ Tel.: +34-93489-4168 (T.A.)
}

Received: 19 March 2018; Accepted: 21 April 2018; Published: 26 April 2018

\begin{abstract}
Connexins are tetraspan transmembrane proteins that form gap junctions and facilitate direct intercellular communication, a critical feature for the development, function, and homeostasis of tissues and organs. In addition, a growing number of gap junction-independent functions are being ascribed to these proteins. The connexin gene family is under extensive regulation at the transcriptional and post-transcriptional level, and undergoes numerous modifications at the protein level, including phosphorylation, which ultimately affects their trafficking, stability, and function. Here, we summarize these key regulatory events, with emphasis on how these affect connexin multifunctionality in health and disease.
\end{abstract}

Keywords: connexins; gap junctions; transcription; translation; post-translational modifications; trafficking

\section{Introduction}

Since the cloning of the first connexins in the 1980s, steady progress towards elucidating their regulation and function as signaling hubs and mediators of direct intercellular communication has been made [1-3]. All connexins share a conserved four-transmembrane domain structure that assembles into hexameric pores known as connexons that can integrate into the cell membrane (Figure 1). Hundreds to thousands of these connexons typically dock with opposing connexons in an adjacent cell, creating intercellular channels forming a clustered gap junction plaque that permits direct flux of ions and small cytosolic signaling molecules between cells, commonly referred to as gap junctional intercellular communication (GJIC) (Figure 1). More recently, connexons have been shown to act as "hemichannels" to facilitate direct exchange of molecules between the cell cytosol and the extracellular milieu under specific conditions [4]. Additionally, numerous noncanonical channel-independent functions have been described, in particular for connexin 43 (Cx43), which are mediated through direct protein interactions and modulation of signaling pathways [5]. The complexity and isoform-specificity of the connexin gene family is reflected by their links to numerous human diseases, many of which are rare syndromes with unique genotype-phenotype associations $[6,7]$. 
This latter phenomenon is underscored by the observation that mutations in different connexins can cause the same disease, whereas varying mutations in one connexin gene can result in vastly divergent diseases and phenotypes. Dysregulation of connexins is also increasingly linked to many common and often morbid medical conditions-such as stroke, heart attack, and cancer-which have been linked to the discovery of an expanding number of new functional attributes through both gap junction-dependent and -independent mechanisms [2,3,6-9]. As such, exploring the clinical and therapeutic potential of connexins as drug targets is pertinent and ongoing [10-12]. Towards this, a deeper understanding of how these genes and proteins are regulated and function is essential. This review aims to summarize and underscore important and unique mechanisms that regulate connexin function in healthy and diseased states, which ultimately shed light on clinical observations and future therapeutic opportunities. 


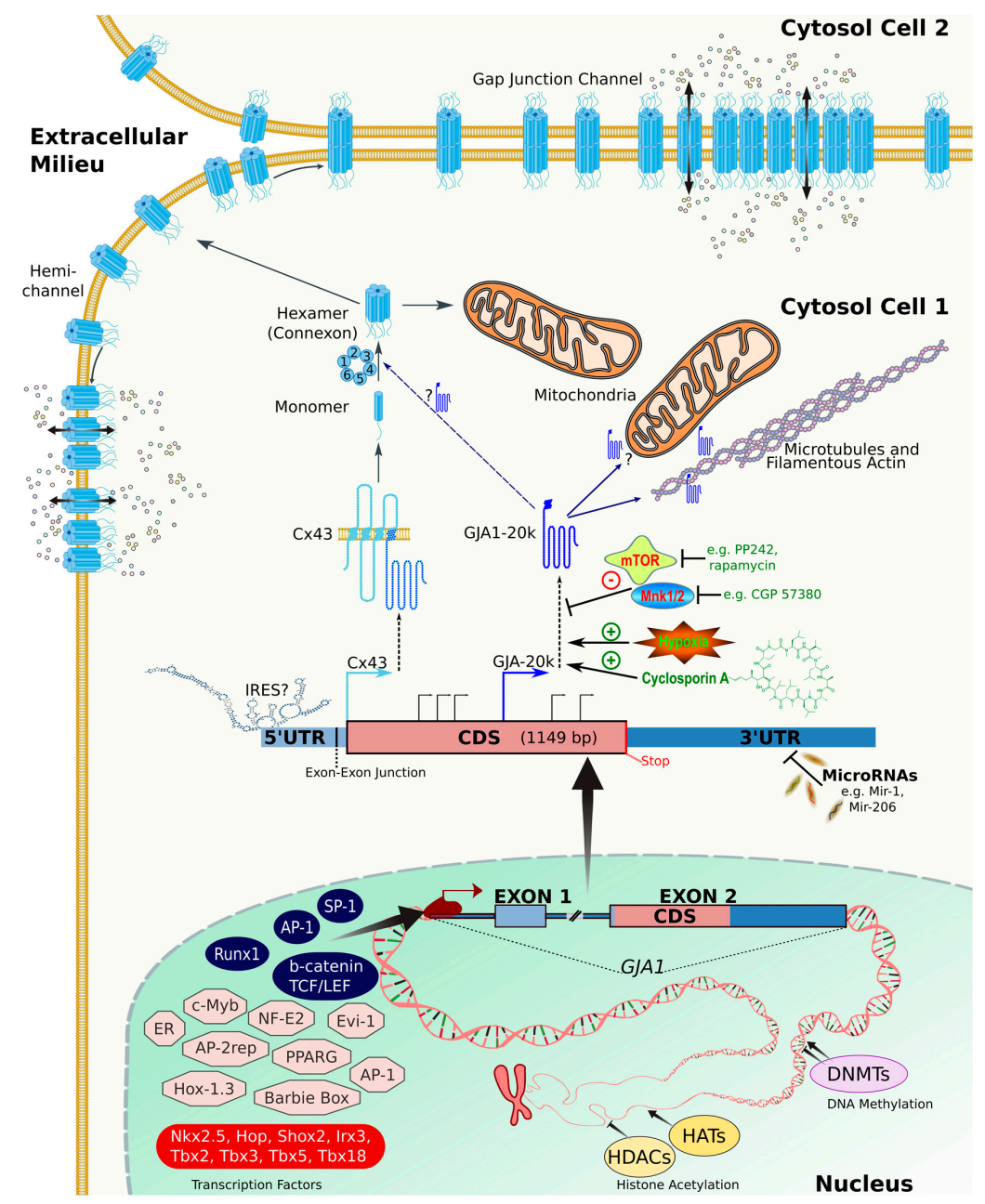

Figure 1. Connexins form hexameric connexons permeable to small molecules acting either as hemichannels or as intercellular channels. The human GJA1 gene, encoding for connexin 43 (Cx43), contains two exons spanning a genomic region of 14,168 bp. Exon 1 contains $256 \mathrm{bp}$ of the $5^{\prime}$ UTR (untranslated region), whereas exon 2 encompasses $16 \mathrm{bp}$ of the $5^{\prime}$ UTR, the entire coding region (1149 bp), and the entire $3^{\prime}$ UTR region (1748 bp). Transcription of mRNA (3169 bp) is under regulation by numerous transcription factors as indicated in this figure and in the main text. Notably, Sp-1 and AP-1 are key regulators of Cx43 mRNA expression (grouped in blue). Multiple tissue-specific promoters are active, which has been well described in the heart (grouped in red). Additional transcription factors (grouped in light red) are derived from promoter analysis using the online Lasagna-Search tool (using a very strict cut-off of $p<0.0001$ and Transfac transcription factor binding sites) [13]. Epigenetics regulate transcription, including through promoter hypermethylation by DNA methyltransferase enzymes (DNMTs). Acetylation by histone acetyltransferase enzymes (HATs) promote transcription, and the reverse reaction is mediated by histone deacetylases (HDACs). The transcript is also regulated by numerous microRNAs (see main text for details). In addition to full-length Cx43 (43 kilodalton (kDa)), the same mRNA can produce multiple truncated forms via internal translation initiation (indicated by arrows within the CDS (coding DNA sequence) of the mRNA, most notably the $20 \mathrm{kDa}$ form named GJA1-20k). Truncated forms are also under translational regulation by a number of pathways such as mechanistic target of rapamycin (mTOR) and mitogen-activated protein kinase (MAPK)-interacting serine/threonine-protein kinase 1 (MNK1) and 2 (MNK2), and can be induced by inhibitors of these pathways as well as by other specific drugs such as cyclosporin A (the positive regulators are depicted in green). GJA1-20k is also induced by pathological states such as hypoxia. The function of GJA1-20k may include interaction with mitochondria and regulation of the actin cytoskeleton as well as regulation of Cx43 oligomerization and trafficking to the membrane. See main text for further details related to the figure. 


\section{Connexins: From Gene to Protein}

\subsection{Gene Structure and Splicing}

Twenty-one human genes and 20 mouse genes encoding for connexin proteins have been identified, of which 19 are considered orthologous pairs [14,15]. The genes tend to have distinct chromosomal locations, although there are some regions of the genome containing clusters of connexin genes [14]. Most connexin genes share a common structure consisting of two exons separated by an intron of variable size. The majority of the $5^{\prime}$ UTR (untranslated region) is localized on exon 1 , whereas the entire coding region and the $3^{\prime}$ UTR are found in exon 2. Some connexin genes contain more than two exons (for the $5^{\prime}$ UTR of the transcript), such as human GJA5 (Cx40) [16], which contains three exons producing two distinct and tissue-specific transcripts, and GJB6 (Cx30), described to contain six exons that allows for tissue-specific splicing [17]. Mouse connexin genes with three or more exons include Gjb1 (Cx32) [18], Gja1 (Cx43) [19], and Gjc1 (Cx45) [20]. In a few cases, the coding region is also distributed over more than one exon [21-24]. A basal promoter (P1) is typically found within $300 \mathrm{bp}$ upstream of the transcription initiation site of exon 1 [25]. However, splice isoforms have been reported due to alternate promoter usage, yielding different transcripts with the coding region being unaltered. As such, a deeper understanding of connexin gene structure, promoter usage, and splicing pattern is required for a full understanding of their impact in connexin-related diseases. For example, the human GJB1 gene encoding Cx32 contains at least three exons (E1, E1B, and the coding exon E2) and produces two different alternatively spliced transcripts by using two tissue-specific promoters (P1 and P2) [26]. It is thus pertinent to include this region in mutational screening of dominant X-linked Charcot-Marie-Tooth (CMTX1) disease, a type of neuropathy that can be caused by mutations in Cx32 leading to defects in Schwann cell function, at least in cases where no mutations are found in the Cx32 coding region. Indeed, recent studies have identified mutations affecting GJB1 splicing [27], and even deletion of the GJB1 P2 promoter [28], as underlying causes of CMTX1. Others have shown that splicing mutations in GJC2 encoding Cx47 can cause a severe form of Pelizaeus-Merzbacher-like disease [29]. Another splice-site mutation, in GJB2 encoding Cx26, has been suggested to cause a mild postlingual onset form of hearing loss [30].

In addition to these more well-described biological phenomena, a few connexin pseudogenes (genes thought to originate from decay of genes that stems from duplication through evolution) have been identified in the human genome. The GJA1 pseudogene (GJA1P) is located on human chromosome 5, whereas the regular GJA1 gene encoding for Cx43 is located on chromosome 6 . Although most pseudogenes are thought to be nonfunctional, GJA1P appears to be transcribed, possibly even translated, and may regulate tumor growth [31,32]. Mutations in GJA1P have also been associated with nonsyndromic deafness [33]. Functionally, GJA1P may influence GJA1 expression levels by acting as a microRNA sponge [34]. In contrast, GJA6P seems to be a nonfunctional pseudogene, originated from the mouse Gja6 connexin gene encoding Cx33, which has no human counterpart (Gene ID: 100126825). Another potential pseudogene has been inferred for GJA4 (Gene ID: 100421028) encoding Cx37. The role of pseudogenes in disease is an emerging field, particularly among genes causing multiple different diseases or syndromic diseases, such as connexins.

\subsection{Transcription Factors and Epigenetics}

Connexins are expressed distinctively in almost all vertebrate cell types (excluding erythrocytes, mature sperm cells, and differentiated skeletal muscle cells) [35]. Some connexins (notably Cx43) are expressed in numerous cell types, whereas others show a more restricted expression profile (e.g., Cx50 that is mainly found in lens cells). Most tissues express multiple connexins. The epidermis of the skin, for example, is thought to express at least 10 different connexins whose expression partially overlap during keratinocyte stratification and differentiation [36-38]. Five of these connexins underlie 11 clinically different cutaneous disorders [37,39]. This spatiotemporal expression pattern is in large part controlled by transcription factors and epigenetic mechanisms. Several transcription factors acting 
as regulators of basal (ubiquitous) or cell-specific gene activity, and their upstream signal transduction pathways, have been implicated in the control of connexin expression (Figure 1). Notably, specificity protein 1 (Sp1), an important basal transcription factor that binds to GC box sequences in promoter regions, has been reported to favor transcriptional initiation of several connexin genes, including Cx26 [40], Cx32 [41,42], Cx40 [16,43-47], and Cx43 [45,48-53]. Examples of other important regulators that control connexin gene expression include: (i) Activator protein 1 (AP1) transcription factor, composed of proteins belonging to the c-Fos, c-Jun, activating transcription factor (ATF), and J domain containing protein( JDP) families that typically promote positive regulation. AP-1 sites have mainly been described in Cx43 [48,54,55], whereas putative sites have been identified in the Cx45 promoter [56]. (ii) The Wnt pathway: activation of this pathway leads to the formation of nuclear $\beta$ catenin/TCF (T-cell factor) complexes that act as transcription factors by binding to specific TCF/LEF (lymphoid enhancer-binding factor) motifs present in the promoter of human GJA1 and mouse Gja1 encoding Cx43 [57]. From a physiological and disease point of view, this may also be relevant. For example, one study showed Wnt signaling could modulate Cx43-dependent GJIC in the heart, which ultimately may contribute to altered impulse propagation and arrhythmia in the myopathic heart [58]. The importance of GJIC in the heart is well documented and several cell-specific transcription factors have been shown to either activate or repress connexin gene expression in this setting (Figure 1 (red box), reviewed in $[25,59])$. These studies have revealed a role of: (i) homeobox proteins, transcription factors with a unique DNA-binding domain that target gene promoter sequences by self-complementarity (e.g., Nkx2.5, Hop, Shox2, Irx3); (ii) T-box (Tbx) proteins, transcription factors that possess a domain that recognizes a DNA binding element (e.g., Tbx2, Tbx3, Tbx5, Tbx18); and (iii) GATA proteins, important regulators of specific gene expression in different tissue (e.g., GATA-4) [25,59].

Besides the well-described transcriptional regulation of the cardiac connexins, other cases of tissue-specific regulation have been reported (for an overview, see [25]). Cx32 transcription has been found to be positively regulated by hepatocyte nuclear factor-1 (HNF-1) via Sp1 in liver cells [60], by the transcription factor Mist1 in secretory pancreatic acinar cells [61], and by the Sox10 in synergy with the early growth response-2 gene (Egr2) in Schwann cells [62]. This exemplifies how different transcription factors act in a tissue-dependent fashion. Complex transcriptional control thus allows for tissue-specific regulation of connexin expression. It also facilitates rapid response to environmental changes, for example, progesterone and estrogen act as positive and negative regulators, respectively, of Cx43 transcription in the myometrium during pregnancy and labor [63]. Transcription factors are also important during pathological states, such as in ischemia, where multiple connexins are emerging as important injury response mediators. Their roles in complex disease, such as cancer, are also being unraveled. In breast cancer, for example, $\mathrm{C} \times 43$ has been proposed to play a biphasic role acting both as a tumor promotor and a tumor suppressor depending on context such as cancer subtype and stage [3]. In this setting, the aforementioned role of progesterone and estrogen as regulators of $\mathrm{Cx} 43$ expression may be of importance. Recent evidence also suggests that the transcription factor FOXP3 directly binds to and inhibits RUNX1 in mammary epithelial cells, whereas in the absence of FOXP3 in breast tumors, RUNX1 downregulates Cx43 expression [64]. Understanding the role of transcription factors will provide further insight into loss and overexpression of connexins during tumor progression and other pathological states.

Connexin expression is also under significant epigenetic regulation (for recent extensive reviews see $[25,65])$. Two major epigenetic mechanisms have been described to regulate transcriptional control: DNA methylation and histone acetylation. Connexin gene inactivation due to hypermethylation of CpG islands in the promoter region has been described in various human carcinomas, including Cx26 in lung [66] and breast [67], Cx32 in a renal cell carcinoma cell line [68], and Cx43 in breast cancer [69]. In addition, a gradual decrease in Cx32 and Cx43 mRNA expression levels is associated with promoter hypermethylation in Helicobacter pylori-associated gastric tumorigenesis [70]. Transcriptional silencing via promoter hypermethylation is mediated by the enzyme DNA methyltransferase (DNMT). The use of demethylating drugs (DNMTs inhibitors), such as 5-aza-2-deoxycytidine and 5-azacytidine, 
has been proposed as a potential therapeutic solution in cancer, as an increase connexin expression and/or GJIC has been demonstrated in specific cases [68,71,72]. However, the correlation between hypermethylation and gene expression is not always direct and differs between connexin isoforms [72].

Histone acetylation and deacetylation-causing chromatin decondensation and condensation, respectively-constitute other important mechanisms of epigenetic regulation of connexin transcription $[25,65]$. While acetylation is catalyzed by histone acetyltransferase (HAT) enzymes and promotes transcription, the reverse reaction is mediated by histone deacetylase (HDAC) enzymes. Histone acetylation also affects connexin expression, and inhibitors of HDAC enzymes (HDACi)—such as trichostatin A, sodium butyrate, and 4-phenylbutarate-have been shown to enhance connexin and GJIC in a variety of cell populations, including in cancer cells [73], in which therapeutic and preventive roles for specific HDACi have been proposed. Histone deacetylase inhibition has also been shown to reduce $\mathrm{Cx} 43$ expression and gap junction communication in cardiac cells [74], which has implications with regards to potential side effects such as slow ventricular conduction or arrhythmias. Therefore, the action of HDACi seems to be connexin- and cell type-dependent. Curiously, Cx43 has been shown to influence histone acetylation of other genes; in a human pulmonary giant cell carcinoma cell line, the follistatin-like 1 (FSTL1) promoter was shown to be associated with acetylated histones H3 and H4 upon Cx43 transfection. Cx43 was proposed to act as a "histone deacetylase inhibitor" that modulates gene expression and inhibits tumor invasion [75].

The potential therapeutic role of epigenetic regulations has broad interest, particularly in complex diseases such as cancer, as exemplified above. However, the nonspecific nature of this gene regulatory mode complicates more direct and specific therapeutic targeting. Moreover, research is needed to determine if connexin levels are mainly mediated via HDACi histone modification [73,76], via non-histone protein modification of transcription factors, or via direct or indirect connexin protein modification such as Cx43 acetylation or phosphorylation [77-79].

\subsection{RNA Stability and MicroRNAs}

MicroRNAs (miRNAs) are short single-stranded noncoding RNAs that can regulate expression at a post-transcriptional level by base pairing to mRNA sequences (usually located at the $3^{\prime}$ UTR region), reducing protein expression levels via mRNA degradation, translational inhibition, or transient mRNA sequestration. Numerous microRNAs have been predicted to downregulate the expression of different connexin genes (for recent reviews see $[65,80]$ ). Cx43 is by far the best studied connexin, and a number of functional microRNAs targeting this gene have been identified, including miR-1, miR-23a, miR-186, miR-200a, miR-206, and miR-381 in human breast cancer [81], miR-20a in human prostate cancer [82], miR-221/222 in glioblastoma multiforme [83], and miR-206, miR-1, and miR-133 in cardiac myocytes and during skeletal myoblast differentiation [84-86].

Regulation of connexin expression by miRNAs has been described to be active in various disease states (for example, in cancer) by affecting hallmarks such as proliferation and invasion $[82,83]$. In therapeutic settings, options include targeting miRNAs that regulate connexins in order to reverse the malignant phenotype. This has been shown in several studies, including in human glioblastoma cells, where inhibition of miR-221/222 activity with antisense oligonucleotides led to the upregulation of Cx43 and restoration of GJIC [83].

As mentioned above, miR-1 acts in cardiac muscle and downregulates Cx43 expression. This has been related to several cardiopathologies in humans, including the regulation of cardiac arrhythmogenic potential [86]. In contrast, loss of miR-1, and thus increased Cx43 expression, has been linked to myotonic dystrophy [87]. Interestingly, a severe congenital heart defect, tetralogy of Fallot, is associated with downregulation of miR-1 and miR-206, which is thought to lead to an increase in Cx43 protein levels [88]. miR-1 downregulation of $\mathrm{Cx} 43$ in the bladder musculature has also been reported to have a role in overactive bladder syndrome [89]. 
Connexins are implicated in joint and bone disease [90]. Cx43 has an important role in osteoblast growth and differentiation, and various miRNAs (including miR-23a [91] and miR144-3p [92]) have been shown to target $\mathrm{C} x 43$ in this setting. $\mathrm{C} x 43$ can also influence the expression of miRNAs themselves, notably miR-21 in osteocytes, a pathway linked to osteocyte apoptosis and osteoclast formation/recruitment [93]. Moreover, direct transfer of miRNAs—-through gap junctions-has been described, and is thought to play a role in bone development [94] as well as in aspects of tumor growth and tumor dormancy [3].

In addition to miRNAs, connexin transcript stability can be regulated by RNA-binding proteins (RBPs), such as human antigen $\mathrm{R}$ (HuR) that stabilizes the Cx43 mRNA by binding adenylate/uridine-rich elements (AREs) present in the Cx43 $3^{\prime}$ UTR [95]. Other examples include S1516-binding protein elements, which may regulate Cx43 expression, particularly in Ras-transformed cancers [96]. For further insight into the epigenetic regulation of connexins, including by miRNAs, we refer to other more exhaustive recent reviews [65,80].

\subsection{Translational Regulation}

\subsubsection{Internal Ribosome Entry Site (IRES)}

Due to the key role of connexins in sustaining many cellular functions and tissue physiology, it has been suggested that connexin expression needs to be maintained at all times, even under conditions where the classical cap-dependent mRNA translation pathway is suppressed, such as during mitosis, apoptosis, differentiation, senescence, or cell stress [97,98]. Several internal ribosome entry site (IRESs) elements have been reported in the mRNA of connexins, notably in Cx43 [99] (Figure 1), Cx32 [100], and Cx26 [101]. An IRES is a nucleotide sequence, usually located within the $5^{\prime}$ UTR of the mRNA, which - in contrast with the canonical translation mechanism-allows for cap-independent translation initiation, a process regulated by specific RBPs also known as IRES trans-acting factors (ITAFs) [102,103]. However, numerous other translation initiation mechanisms are thought to exist [104] and whether true IRES-mediated translation occurs in the aforementioned connexins and other family members, is subject to caution, and additional specific molecular assays are warranted [105]. Additional work is also needed towards elucidating their functional relevance. One study suggests that IRES-mediated translation of $\mathrm{Cx} 26$ and $\mathrm{C} \times 43$ occurs in density-inhibited cancer cells (where cap-dependent translation is reduced), thus leading to the induction of GJIC and potentially reduced tumor growth [101]. Some data also points towards an important role of IRES-translation of connexins in human physiology. Notably, a specific mutation in the $5^{\prime}$ UTR IRES sequence of Cx32 is linked to neurodegenerative Charcot-Marie-Tooth disease [100].

\subsubsection{Alternative Translation of Truncated Connexin Forms}

Most IRES sequences are located in the 5' UTR, yet a few examples exist (notably Notch2 [106]) where an IRES sequence is located within the coding region, allowing translation of truncated protein forms. A similar mechanism has been proposed for Cx55.5 in zebrafish, in which an 11 kilodalton $(\mathrm{kDa})$ truncated C-terminal form is produced and localizes to the nucleus of outer retina cells $[107,108]$.

In mammalian cells, the presence of truncated forms of $\mathrm{Cx} 43$ is often observed in immunoblots. In particular, a $20 \mathrm{kDa}$ form (named GJA1-20k) is highly prevalent in cultured cells, which was described to arise from the $\mathrm{C} \times 43$ coding sequence and correspond to the C-terminal tail [109]. More recently, Smyth and Shaw described that GJA1-20k and several other less prevalent truncated forms can occur in normal tissue, and is due to internal translation initiation events [110]. Multiple groups have now confirmed this observation and further delineated key regulatory pathways, such as the mechanistic target of rapamycin (mTOR) [110,111] and the mitogen-activated protein kinase (MAPK)-interacting serine/threonine-protein kinase 1 (MNK1) and 2 (MNK2) [111] signaling cascades. Additionally, regulation occurs in response to important physiological conditions such as hypoxia [112] (Figure 1). Although an internal IRES element has been suggested [112], evidence suggests a 
highly unusual cap-dependent mechanism is critical for the efficient synthesis of these truncated forms $[80,111]$.

The C-terminus of Cx43 has been extensively studied and is implicated in the regulation of a variety of biological events such as cell migration and proliferation, neuronal differentiation, and cytoskeletal changes (for a recent review see [5]). However, functional roles for specific internally truncated forms of $\mathrm{C} \times 43$ are currently being elucidated. Thus far, GJA1-20k has been shown to act as a potential chaperone for $\mathrm{C} \times 43[110,113]$ that facilitates microtubule-based mitochondrial transport and mitochondrial network integrity [114] (for details, see Section 4.3). Additionally, loss of GJA1-20k (but not full-length Cx43) has been reported in early-stage human breast cancers, followed by its re-expression in cell lines regulated by p53 activation via miR-125b [115]. Roles for these truncated forms of connexins in complex genetic disease is of future interest considering recent advancements in the potential for pharmacologic modulation of internal translation [80].

\section{Post-Translational Regulation of Connexins}

Post-translational modification of connexin proteins regulates many important aspects of their life-cycle, including synthesis, trafficking, channel gating, and protein-protein interactions. While highly conserved, variations occur throughout the connexin family in protein sequence, size of intracellular N-/C-terminus, and loop regions. Connexin extracellular loop regions contain disulfide bridges that form between cysteines to maintain membrane topology and facilitate docking with opposing connexons, allowing the formation of gap junctions [116]. Unlike many other membrane-bound proteins, connexins are not glycosylated, with membrane trafficking and protein folding being regulated through alternative pathways (for details, see Section 4). The relatively unstructured nature of intracellular connexin domains makes for an ideal environment for post-translational modification to induce conformational changes that regulate protein-protein interactions. The majority of connexins contain multiple consensus sites for modifications through phosphorylation, S-nitrosylation, SUMOylation, and others. There have been several recent and comprehensive reviews on connexin post-translational modifications [5,117-119]. Instead of recapitulating these articles, we will highlight some of the main aspects of post-translational modifications of connexins and discuss their relevance in human disease.

\subsection{Phosphorylation}

Phosphorylation is a key regulator of connexin proteins, hemichannels, and gap junction channels [120-122]. The addition of phosphate groups to specific amino acids-including serine (Ser, S), threonine (Thr, T), or tyrosine (Tyr, Y)-leads to changes in charge, hydrophobicity, and potential alterations in protein structure resulting from formation of hydrogen bond networks [123]. These can alter the way the connexin protein interacts with itself (e.g., channel regulation) or with other proteins (e.g., trafficking and protein-protein interactions).

Phosphorylation has been reported in a large number of connexins, e.g., Cx31 [124], Cx32 [125-127], Cx37, Cx40 and Cx45 [128,129], Cx43 [130,131], Cx46 and Cx50 [132-134], and Cx47 [135]. The majority of phosphorylation events are reported within the connexin C-terminus, with the exception of Cx26, which is not phosphorylated in its short 11 a.a. C-terminus $[136,137]$. However, mass spectrometry has demonstrated multiple potential Cx26 phosphorylation sites in the N-terminus, which are differentially regulated by hydroxylation, and further putative sites in the cytoplasmic loop, although the functions of these Cx26 phosphorylation sites are unknown [138,139]. There are some reports of intracellular loop phosphorylation—such as Cx56 [140] and Cx35 [141]-although this does not appear to be the case for $\mathrm{Cx} 43$ or other connexins $[5,142,143]$. There are no reports of N-terminus phosphorylation in other connexins, although Cx43-Ser5 is a potential candidate site [144]. The C-terminus of connexins are intrinsically disordered protein (IDP) regions with a high Ser/Thr/Tyr content, as described for Cx32, Cx40, Cx43, Cx45, and Cx50 [145-149]. Stable $\alpha$-helical regions have been identified by nuclear magnetic resonance (NMR) and circular dichroism (CD) in 
the C-terminus of Cx43 [146,150] and other connexins, for example, Cx37, Cx45, and Cx50 [151-154]. However, stable alpha-helices are not a common feature of the connexin C-terminus. For instance, Cx40 only forms dynamic alpha-helices between Cys267-Gly285 [155]. Several lines of evidence-such as electrophoretic shifts on SDS-PAGE gels and NMR analysis-suggest that phosphorylation by enzymes, such as MAPK and Protein Kinase C (PKC), result in differential, transient increases in connexin C-terminal alpha-helical content [128,149,156-158].

The significance of the formation of alpha-helical domains is the potential for higher order secondary structures that regulate channel gating and protein partner binding. In $\mathrm{Cx} 43$, it has been demonstrated that the $\mathrm{C}$-terminus interacts with the intercellular loop to regulate channel functions in a "ball-and-chain" type mechanism $[159,160]$, although other factors relating to phosphorylation (e.g., charge and hydrophobicity) may also influence channel gating. Multisite phosphorylation of proteins is known to alter protein half-life, docking, and intracellular localization, which may also influence gap junction signaling $[148,149,161]$. Connexin 43 , the most widely studied of the connexin family, has 30 putative phosphorylation sites which have been extensively demonstrated to be post-translationally modified, leading to alterations in gap junction signaling. For detailed reviews of these phosphorylation sites and their effects on channel regulation see [5,143,144,162-164]. The effects of post-translational modifications on connexins are also shown in Table 1.

Table 1. Connexin post-translational modifications (PTMs) and functional effects.

\begin{tabular}{|c|c|c|c|c|}
\hline Connexin/Residue & PTM & GJIC & Expression & Refs. \\
\hline \multicolumn{5}{|l|}{ Cx26 ${ }^{\text {m.s./a: }}$} \\
\hline $\begin{array}{l}\text { M1/K15/K102/ } \\
\text { K103/K105/ } \\
\text { K108/K112/K116 }\end{array}$ & Acetylation & ND & ND & \multirow{5}{*}[138,139]{} \\
\hline $\begin{array}{l}\text { N14/N113/ } \\
\text { N170/N176 }\end{array}$ & Hydroxylation & ND & ND & \\
\hline E42/E47/E114 & carboxylation & ND & ND & \\
\hline $\begin{array}{l}\text { K61/R75/ } \\
\text { K221/K223 }\end{array}$ & Methylation & ND & ND & \\
\hline $\begin{array}{l}\mathrm{T} 123 / \mathrm{T} 177 / \mathrm{S} 183 / \\
\mathrm{T} 186 /(\mathrm{Y} 233 \text { or } \\
\mathrm{Y} 235 \text { or Y240) }\end{array}$ & Phosphorylation & ND & ND & \\
\hline \multicolumn{5}{|l|}{ Cx31(m): } \\
\hline $263^{b}$ & CK1 & No change & No change & [124] \\
\hline $266^{\mathrm{b}}$ & CK1 & No change & No change & [124] \\
\hline \multicolumn{5}{|l|}{ Cx32: } \\
\hline S229 & PKC & Increase/Decrease & Increase/Decrease & [165] \\
\hline S233 & PKA/PKC & Increase/Decrease & Increase/Decrease & {$[120,138,165,166]$} \\
\hline S240 & ND & ND & ND & [138] \\
\hline Y7/Y243 & EGFR tyrosine kinase & ND & ND & [167] \\
\hline \multicolumn{5}{|l|}{ Cx35/Cx36: } \\
\hline S110 & PKA/PKG & No change & Decrease & {$[141,168-170]$} \\
\hline S276/293 & PKA/PKG & No change & Decrease & {$[141,168-171]$} \\
\hline S289 & PKG (NO mediated) & ND & Decrease & [170] \\
\hline \multicolumn{5}{|l|}{ Cx37: } \\
\hline $\begin{array}{l}\text { S275/S285/ } \\
\text { S302/S319/S321/ } \\
\text { S325/S329 }\end{array}$ & PKC & Increased & Decrease & [128] \\
\hline
\end{tabular}


Table 1. Cont.

\begin{tabular}{|c|c|c|c|c|}
\hline Connexin/Residue & PTM & GJIC & Expression & Refs. \\
\hline \multicolumn{5}{|l|}{ Cx43: } \\
\hline S5 m.s. & ND & ND & ND & [144] \\
\hline K144 & SUMO & Increase & Increase & [172] \\
\hline K237 & SUMO & Increase & Increase & [172] \\
\hline S244 m.s. & CAMKII & ND & ND & [173] \\
\hline $\mathrm{Y} 247^{\mathrm{c}}$ & Src & Decrease & Decrease $^{c}$ & {$[120,146,174-178]$} \\
\hline \multirow{3}{*}{ S255 m.s. } & CAMKII & ND & ND & [173] \\
\hline & P34cdc2 & Decrease & Decrease & {$[179,180]$} \\
\hline & MAPK & No change/Decrease & No change & {$[120,131,148,181]$} \\
\hline S257 m.s. & PKG/CAMKII & ND & ND & [173] \\
\hline \multirow{3}{*}{$\mathrm{S} 262^{\mathrm{d}}$} & P34cdc2 & Decrease & Decrease & {$[179,180]$} \\
\hline & MAPK & Decrease & Decrease/no change & {$[120,131,148,182,183]$} \\
\hline & $\mathrm{PKC} \varepsilon^{\mathrm{a}}$ & Decrease & Decrease & {$[131,181,182]$} \\
\hline$Y 265^{c}$ & Src & Decrease & Decrease $^{c}$ & {$[120,146,174-178]$} \\
\hline $\mathrm{C} 271$ & Nitrosylation & Increase & No change & [184] \\
\hline \multirow{2}{*}{ S279 e } & MAPK & \multirow{2}{*}{ Decrease } & Decrease/no change & {$[131,148,174]$} \\
\hline & CDK5 & & Decrease & [185] \\
\hline \multirow{2}{*}{$\mathrm{S} 282^{\mathrm{e}}$} & MAPK & Decrease & Decrease/no change & {$[131,148,174]$} \\
\hline & CDK5 & Decrease & Decrease & [185] \\
\hline S296 m.s. & CAMKII & ND & No change & {$[173,186]$} \\
\hline S297 m.s. & CAMKII/PKC $\varepsilon$ & ND & No change & {$[173,186]$} \\
\hline S306 m.s. & CAMKII & Decrease & $\begin{array}{l}\text { Decrease associated } \\
\text { with De-Phosph. }\end{array}$ & {$[173,186,187]$} \\
\hline S314 m.s. & CAMKII & ND & ND & [173] \\
\hline \multirow{2}{*}{ S325 m.s. } & CAMKII & ND & ND & [173] \\
\hline & CK1 & Increase & Increase & [188] \\
\hline \multirow{2}{*}{$\mathrm{S} 328^{\mathrm{m} . s .}$} & CAMKII & ND & ND & [173] \\
\hline & CK1 & Increase & Increase & [188] \\
\hline \multirow{2}{*}{$\mathrm{S} 330^{\mathrm{m} . \mathrm{s}}$} & CAMKII & ND & ND & [173] \\
\hline & CK1 & Increase & Increase & [188] \\
\hline \multirow{2}{*}{$\mathrm{S} 364^{\mathrm{m} . s .}$} & CAMKII & ND & ND & [173] \\
\hline & PKA & Increase & Increase & [120,189-191] \\
\hline \multirow{3}{*}{ S365 m.s. } & CAMKII & ND & ND & [173] \\
\hline & PKA & Increase & Increase & \\
\hline & PKC & Decrease & Decrease & {$[120,192-194]$} \\
\hline \multirow{2}{*}{$\mathrm{S} 368^{\mathrm{f}}$} & $\mathrm{PKC} \alpha$ & Increase/Preserved/ & Increase & [192-196] \\
\hline & $\mathrm{PKC} \varepsilon$ & Decrease $^{g}$ & Decrease & [120,193-199] \\
\hline \multirow{3}{*}{ S369 m.s. } & CAMKII & ND & ND & \\
\hline & PKA & Increase & No change & [173] \\
\hline & PKC & Increase & Increase & {$[5,120,192-194]$} \\
\hline \multirow{2}{*}{ S372 m.s. } & CAMKII & ND & ND & [173] \\
\hline & PKC & Decrease & Decrease & {$[5,148,192,193,200,201]$} \\
\hline \multirow{4}{*}{ S373 g,m.s. } & Akt & Increase & Increase $^{\mathrm{e}}$ & {$[200,201]$} \\
\hline & CAMKII & ND & ND & [173] \\
\hline & PKC & Decrease & Decrease & \\
\hline & PKA & Increase & Increase & {$[120,148,192-194]$} \\
\hline
\end{tabular}


Table 1. Cont.

\begin{tabular}{|c|c|c|c|c|}
\hline Connexin/Residue & PTM & GJIC & Expression & Refs. \\
\hline \multicolumn{5}{|l|}{ Cx45: } \\
\hline $\begin{array}{l}\text { S326/Y337/ } \\
\text { S381/S382/S384/ } \\
\text { S385/S387/S393 m.s. }\end{array}$ & CAMKII & ND & ND & [129] \\
\hline $\begin{array}{l}\text { S326/S382/S384/ } \\
\text { S387/S393 m.s. }\end{array}$ & CK1 & ND & ND & [129] \\
\hline \multicolumn{5}{|c|}{ Cx46 (Cx56 Chick homologue): } \\
\hline S118 & $\mathrm{PKC} \varepsilon$ & ND & Decrease & {$[140,202]$} \\
\hline \multicolumn{5}{|l|}{ Cx50: } \\
\hline S363 & CK1 & Increase & Increase & {$[120,193]$} \\
\hline \multicolumn{5}{|c|}{ 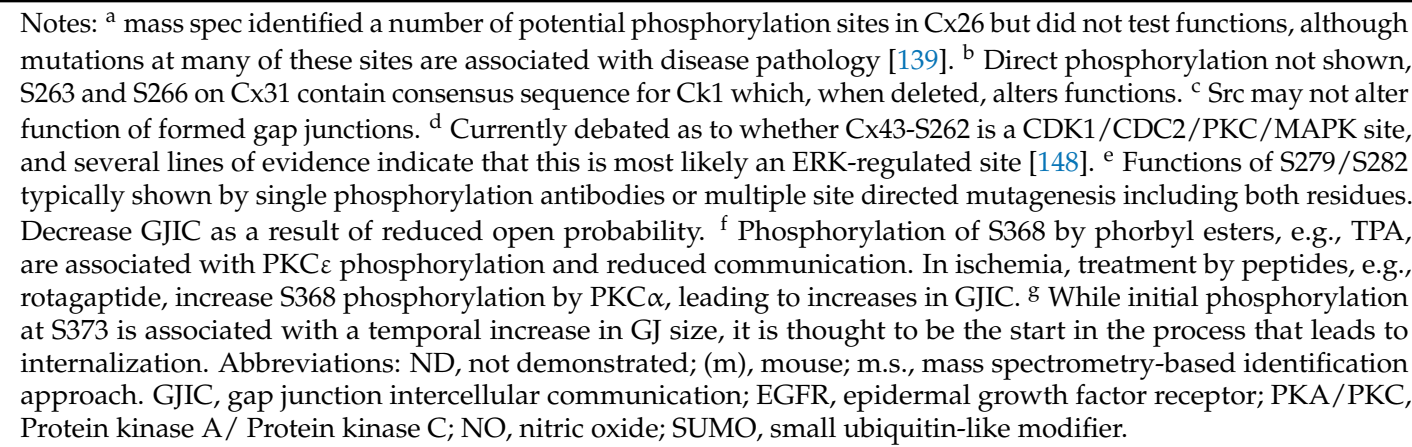 } \\
\hline
\end{tabular}

Phosphorylation is a key regulator of physiological states in tissues, and changes in the phosphorylation status has been observed in several disease states. Within the vasculature, heterocellular endothelial cell-smooth muscle cell contacts, called the myoendothelial junctions (MEJs), express $\mathrm{Cx} 37, \mathrm{Cx} 40$, and $\mathrm{Cx} 43$, allowing for the direct exchange of intercellular signaling ions and molecules such as $\mathrm{Ca}^{2+}$ and $\mathrm{IP}_{3}[203,204]$. At the MEJ, Cx43 and $\mathrm{Cx} 37$ are regulated by post-translational modifications, including phosphorylation and S-nitrosylation (for details, see Section 3.2). In vitro and ex vivo data demonstrate that gap junctions at MEJs allow for the movement of $\mathrm{Ca}^{2+}$ and $\mathrm{IP}_{3}$ between endothelial and vascular smooth muscle cells, which is in part regulated via Cx43-Ser368 [205].

In the healthy heart, $\mathrm{C} \times 43$ is primarily localized to the intercalated disc region of cardiomyocytes. Opening of Cx43-containing channels and signal conduction is facilitated by phosphorylation at residues including Ser365, 325, 328, and 330 [206-208]. Phosphorylation acts as a molecular switch, regulating gap junction opening. In ventricular arrhythmias following myocardial infarction, raised intracellular $\mathrm{Ca}^{2+}$ concentration leads to de-phosphorylation of Cx43-Ser365, which acts as the gatekeeper to phosphorylation of Cx43-Ser368. This resulting increase in Cx43-Ser368 reduces GJIC and promotes a redistribution of $\mathrm{C} x 43$ to lateral regions of the cardiac myocytes, disrupting signaling in the heart [208-210].

Formation of large cardiac gap junction plaques at the intercalated disc is modulated through Cx43 interactions with zonula occludens 1 (ZO-1) [211-214]. In turn, this protein-protein interaction is regulated by PKC phosphorylation of $\mathrm{Cx} 43$ at Ser368, which inhibits ZO-1-mediated disassembly of gap junctions [215]. In ischemic heart disease, Cx43 is lost at the intercalated disc, but Cx43-Ser368 phosphorylation can act to indirectly stabilize the protein [196]. Multiple studies have investigated the effects of targeting the C-terminus of Cx43 in ischemia/reperfusion injuries, reducing infarct size, and other diseases $[11,216]$. A peptide that mimics the terminal region of the Cx43 known as ACT1 can disrupt Cx43/ZO-1 interaction [214,217]. This peptide promotes phosphorylation of Cx43-Ser368 via upregulation of $\mathrm{PKC} \varepsilon$ activity, inhibits $\mathrm{Cx} 43-\mathrm{ZO}-1$ binding, and improves cardiac function following ischemic insult in mice [215]. Similar results have been found for other connexin mimetic peptides targeting the Cx43 C-terminus (e.g., antiarrhythmic peptide 10 (AAP10) and rotigaptide (ZP123)), causing increases in Cx43-Ser368 phosphorylation through PKC $\alpha$ (reported to stabilize protein 
expression and increase GJIC) associated with improved cardiac functions in experimental animal models and early tests demonstrating no adverse effects in humans [192,218-222]. However, it should be noted that a similar peptide, danegaptide (a stabilized form of rotigaptide), failed to change clinical outcomes in ischemic reperfusion injuries in human Phase II testing (NCT01977755, completed 2016) [223].

In vascular disease, phosphorylation-mediated connexin-protein interactions and GJIC have been found to regulate disease state. Oxidized phospholipids found within atherosclerotic plaques increase MAPK and PKC phosphorylation of $\mathrm{Cx} 43$ and are associated with increased inflammation and cellular proliferation [130,224-227]. In response to the release of growth factors in disease, Cx43 is phosphorylated at MAPK residues (Cx43-Ser255, -Ser262, -Ser279, -Ser282), promoting direct interactions with the cyclin E/CDK2 complex and enhancing smooth muscle cell proliferation [131]. Conversely, PKC phosphorylation of Cx37 alters GJIC, which is linked with growth suppressive effects (e.g., reducing vasculogenesis and angiogenesis) [228-233]. Mutation of all seven Cx37 Ser > Ala essentially closes Cx37 GJs and hemichannels and inhibits both proliferation and cell death, whereas mutation of only three (Cx37-Ser275, -Ser302 and -Ser328) partially inhibits channel opening and decreases cellular death in rat insulinoma cells [128].

Phosphorylation also plays an important role in altered localization and function of connexins in cancer [3]. Several oncogenes and proto-oncogenes robustly inhibit GJIC, including HRAS [234], c-Src [235], and v-Src [178]. Curiously, the tyrosine-protein kinase c-Src has a reciprocal relationship with $\mathrm{C} x 43$ that regulates its activity, where $\mathrm{Cx} 43$ is shown to bind with phosphatases (e.g., PTEN and Csk) reducing c-Src activity [236]. Conversely, Src phosphorylation of tyrosine residues on Cx43 (Cx43-Tyr243/-Tyr265) mediates interactions with endosomal machinery, leading to internalization of Cx43 and reduced expression [118,237]. Numerous tumor promoters, such as phorbol esters, also rapidly inhibit Cx43-mediated GJIC [238-240] through PKC- and ERK-mediated phosphorylation events $[181,241]$. On the contrary, loss of phosphorylation can also negatively affect GJIC. One recent study showed that the levels of total Cx43 protein and Cx43 phosphorylated at Ser368 and Ser279/282 were high in normal tissue but low to absent in malignant pancreatic tissue [79]. Altered Cx43-phosphorylation can be indicative of prognosis in some tumors, such as gliomas [242]. Phosphorylation of other connexins can also affect GJIC and the cancer phenotype, notably PKC-mediated phosphorylation of Cx37 [128]. Targeting dysregulated phosphorylation events of connexins in cancer may be one therapeutic angle towards restoring connexin function or GJIC. Indeed, the chemotherapeutic drug gefitinib has been suggested to upregulate GJIC by inhibiting Src and PKC-modulated Cx43 phosphorylation [243]. However, resistance to cisplatin-based chemotherapy has been suggested to be due to Src-induced Cx43 phosphorylation and loss of GJIC [244].

During wound healing, phosphorylation may also play a role in coordinating GJIC and connexin redistribution [245-247]. Initial responses to wounding include a generalized loss in Cx43, which may be modulated by increases in cyclic adenosine monophosphate (cAMP). In wound models, 8-bromo-cAMP-treated embryonic stem cells promote enhanced wound repair associated with reduced membrane bound Cx43, disruption in Cx43-ZO-1 interactions, and reduced GJIC [248]. However, the mechanisms regulating this are unclear, since cAMP-associated kinases have been previously described to increase PKA-mediated Cx43 synthesis, phosphorylation (Cx43-Ser364), GJ assembly, and GJIC in other model systems $[189,249]$. Phosphorylation is extremely dynamic within the wound and appears to be coordinated with the stage of repair. Initial increases in Cx43-Ser373, driven by AKT, can be seen between 1 and $30 \mathrm{~min}$ after wounding occurs, disrupting interactions with ZO-1, initially stabilizing Cx43 at the membrane, but is followed by rapid internalization of Cx43 [200]. Following wounding, transient increases (24-72 h) in PKC-mediated Cx43-Ser368 phosphorylation in regions proximal to the injured sited are associated with a loss of GJIC [250,251]. These data and others suggest that a combination of phosphorylation events sequentially regulate connexin signaling during wound repair [252]. 
In disease states such as diabetes, nonhealing wounds lead to complications, including ulcerations in skin tissues. In streptozotocin-induced diabetic mice, $\mathrm{Cx} 43$ dynamics are different from normal skin tissues, with increased expression of dermal Cx43 associated with reduction in keratinocyte migration [253]. Similar observations have been made in human diabetic ulcers, with Cx43 found to remain at elevated levels as compared to normal skin wounds [254]. In vitro and ex vivo evidence suggests that peptides aimed at disrupting gap junction and hemichannel communication (e.g., Gap27) can improve wound healing, which is associated with increased Cx43-Ser368 phosphorylation [251]. Recent studies have also shown that increases in Cx43-Ser368 phosphorylation following topical application of the ACT1 peptide is associated with clinically significant improvements in scar reduction and wound closure rates [255].

\subsection{S-Nitrosylation}

S-Nitrosylation occurs through covalent binding of nitric oxide (NO) to reactive cysteine(s) and can result in structural alterations of proteins leading to functional changes [256]. Protein S-nitrosylation is highly dependent on the cysteine oxidation state and surrounding amino acids, meaning that not all cysteines in a protein can be $S$-nitrosylated. While there are cysteine residues on the extracellular loops of all connexins, these have not been demonstrated to be $S$-nitrosylation targets [257]. Within the C-terminus of Cx43, there are three cysteines (Cx43-Cys260,-Cys271, and -Cys298), but only Cx43-Cys271 has been demonstrated to be $S$-nitrosylated, leading to an increase in GJ permeability in endothelial cells and at the MEJ [184]. Direct S-nitrosylation of other connexins has not been demonstrated, although there are multiple lines of evidence demonstrating that nitric oxide (NO) activation leads to regulation of gap junction and hemichannel signaling [258]. Within the vasculature, NO plays an important role in vasodilation. Figueroa et al. found that vascular connexins channels formed by $\mathrm{Cx} 37, \mathrm{Cx} 40$, and $\mathrm{Cx} 43$ are activated by and directly permeable to NO, and have suggested that this is an alternative method to NO transfer across plasma membranes [259]. Cx37 is enriched at the MEJ of resistance arteries and is reported to be important in the regulation of NO-mediated $\mathrm{Ca}^{2+}$ regulation via reducing $\mathrm{C} \times 37$-mediated gap junctional coupling between endothelial cells and smooth muscle cells [260]. However, unlike Cx43, the effects of $\mathrm{NO}$ on Cx37 gap junction channels are thought to be indirect, with no known cysteine modification occurring. Rather, the phosphorylated tyrosine residue (Cx37-Tyr332) is protected from de-phosphorylation by Src homology region 2 (Shp2) phosphatase, which is inhibited in the presence of NO, reducing MEJ transfer of $\mathrm{Ca}^{2+}$ signaling through Cx37 GJ [261]. Thus, S-nitrosylation appears to have diverse effects, depending on GJ composition particularly at the MEJ [261].

\subsection{Other Post-Translational Modifications: SUMOylation, Ubiquitination, and Acetylation}

A number of post-translational modifications are associated with regulation of connexin protein turnover, for example, ubiquitination, SUMOylation, and acetylation. Small ubiquitin-like modifier proteins (e.g., SUMO-1/-2/-3) interact with lysine residues on proteins, altering protein targeting and turnover [262]. So far, there is only evidence for direct Cx43 SUMOylation at lysine residues (Cx43-Lys144, -Lys237) within its intracellular loop and C-terminus [172]. Overexpression of all three SUMO proteins in HeLa cells increases Cx43 expression, promotes gap junction formation, and increases signaling. However, the exact mechanism by which SUMOylation regulates protein expression is not known. The amino acids sequences surrounding Cx43-Lys144 and Cx43-Lys237 are not common motifs associated with SUMOylation, although the same motifs of a conserved Lys144 followed by an upstream large hydrophobic amino acid (valine) are found in at least six other connexins, suggesting a common regulatory pathway [172].

Once at the plasma membrane, the majority of connexins are rapidly turned over with half-lives estimated between 1.5 and $5 \mathrm{~h}$ for $\mathrm{Cx} 43$ and $\mathrm{C} \times 26$ and up to $24 \mathrm{~h}$ for other isoforms such as Cx46 [124,263-266]. While connexins use a multitude of pathways for internalization and degradation, the process typically involves formation of an endosome (termed connexosome [267]), where older 
gap junctions are internalized to be targeted to the lysosome for degradation, although there is also evidence for endosomal recycling back to the membrane $[214,268,269]$. Endosomal formation is driven by multiple proteins in complex, including interactions with ZO-1, tubulin, and others. In the case of $\mathrm{Cx} 43$, this interaction (with ZO-1) is regulated via Cx43-Ser373 and Cx43-Ser368 phosphorylation $[200,214,270,271]$. Monoubiquitinylation typically acts as a signal for internalization of proteins via endosomes to lysosomes, leading to degradation [272,273]. Multiple covalently linked ubiquitin molecules bind lysine residues within the target protein, which are then recognized by receptors and targeted for degradation by the 26S proteasome [274-276] and by autophagy [277-279]. Recent evidence has demonstrated a complementary role for $\mathrm{Cx} 43$ in regulating autophagy, in that Cx43 at the plasma membrane interacts with several pre-autophagosomal proteins, including Atg16, but not other autophagosome proteins, such as LC3 [280]. When the cells are under stress, such as nutrient depletion, $\mathrm{C} \times 43$ becomes ubiquitinylated and internalized, causing recruitment of other factors (Atg5, Atg12, and LC3) to form fully functional autophagosomes. While regulated autophagy can have a protective effect in stressed cells, there is also evidence linking aberrant autophagy and Cx43 degradation from intercalated discs to heart failure [281], suggesting the potential for a novel pharmacologic approach to treat cardiac failure.

Proteasomal-ubiquitin pathways have been proposed to indirectly regulate $\mathrm{C} \times 43$ through interaction with the $\mathrm{ZO}-1$ protein, thus disrupting part of the process that is critical for $\mathrm{Cx} 43$ membrane organization [214,282]. Multiple studies suggest that other connexin proteins (e.g., Cx50, Cx43, and $\mathrm{Cx31.1)}$ are regulated by ubiquitination [283]. Several studies show that ubiquitin regulates internalization of $\mathrm{Cx} 43$ via clathrin-mediated endocytosis, by both tyrosine (Y)-dependent sorting signal ( $Y X X \Phi$, where $X$ is any amino acid and $\Phi$ is an amino acid with a bulky hydrophobic side chain) and tyrosine-independent, EPS15-dependent pathways [284,285]. However, the route through which ubiquitin regulates the connexins has not been fully delineated, with studies in Cx43 demonstrating that the C-terminal lysines are dispensable for protein turnover [286]. Despite this, there is increasing evidence that $\mathrm{C} \times 43$ is modified in response to ubiquitin, and corresponding ligases are controlled in part by phosphorylation events, such as MAPK and PKC phosphorylation [287,288]. A number of ubiquitin-binding proteins (e.g., EPS15, p62, Hrs, and TSG101) are rec ruited to Cx43 to facilitate its internalization and sorting to the lysosome $[289,290]$. In addition, TSG101 has been found to interact with Cx30.2, Cx31, Cx36, and Cx45 [290]. While classic lysine-based motifs may not be responsible for direct ubiquitin binding, more recent studies have shown that proline-rich regions of the Cx43 C-terminus (xPPxY) bind to ubiquitin ligase. A number of ubiquitin ligases have also been associated with direct binding, internalization, and degradation of Cx43 (e.g., Trim21 [291], WWP1 [292], SMURF2 [293], and NEDD4 [287-289,294]). NEDD4 also has been directly associated with loss of Cx43 at the plasma membrane in experimental models [287].

The process of degradation may be further regulated by connexin N-terminal acetylation, which can act to regulate protein stability in the membrane. In mouse cardiac myocytes, N-terminal acetylation through binding of P300/CBP-associated factor with Cx43 leads to a loss of Cx43 at the intercalated disc, a lateral reorganization of the protein, reduced gap junction formation in cardiac myocytes, and internalization in NIH-3T3 (mouse embryo) fibroblasts [77]. These patterns of disorganization of Cx43 are similar to those seen in mouse models of Duchenne cardiomyopathies, where $\mathrm{NO}$ and oxidative stress lead to an imbalance in acetylation/deacetylation and alterations in cardiac conduction. Similarly in dogs, cardiac pacing leads to increased Cx43 acetylation, suggesting that this mechanism is important in regulating signaling in physiology and pathology of the cardiac system $[77,295,296]$.

\section{Connexin Trafficking}

Formation of gap junctions by connexins is regulated by the delivery of newly synthesized channels to the plasma membrane and is balanced by the removal of channels via endocytosis [263,297,298]. As mentioned above, since connexin turnover is generally quite rapid and influenced by post-translational 
modifications, the dynamic regulation of connexins by secretion and turnover provides a means to control gap junction formation, composition, and, thus, GJIC.

\subsection{Control of Oligomerization}

Secretion of newly synthesized connexins from the endoplasmic reticulum (ER) through the Golgi apparatus is coordinately regulated with oligomerization into hexameric hemichannels [299]. Based on structural homology, connexins can be separated into two distinct oligomerization groups. GJB1-GJB7 (so-called $\beta$ connexins, including Cx26 and Cx32) follow a more traditional pathway, where full oligomerization into hexamers is required prior to transport from the ER to the cis-Golgi apparatus [300-302]. By contrast, other connexins are stabilized by a connexin-specific quality control apparatus as monomers that are subsequently transported to the trans-Golgi network (TGN) where they then have the capacity to oligomerize [301,303]. The best-studied connexin known to oligomerize in the TGN is Cx43, although there is also experimental evidence for $\mathrm{Cx} 40$ and $\mathrm{Cx} 46$ oligomerization late in the secretory pathway $[304,305]$. By homology, it is likely that most non-beta connexins will also follow the late oligomerization pathway that has been demonstrated for Cx43 [299].

Several lines of evidence suggest that the transition from monomeric to hexameric $\mathrm{Cx} 43$ requires a conformational change, largely centered on the third transmembrane domain (TM3) where it is stabilized in a monomeric conformation by motifs containing charged amino acids on both ends of the TM domain (Figure 2) [300,305]. At the cytoplasmic interface of the Cx43 TM3 domain is an LR motif containing a highly charged arginine residue, and at the extracellular interface is a glutamine-containing motif with a QYFLYGF amino acid consensus sequence. The extracellular loop domain of Cx43 also interacts with a chaperone protein, ERp29, that is required to stabilize monomeric Cx43 [300].

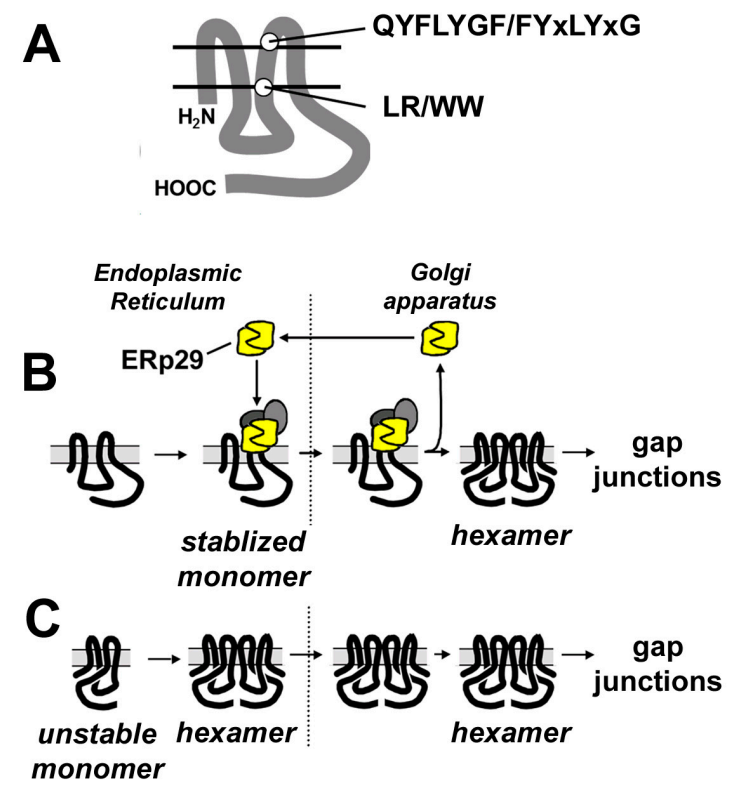

Figure 2. Differential connexin oligomerization. (A) Line diagram showing two key connexin motifs adjacent to the third transmembrane domain. Connexins (such as Cx43), which oligomerize in the Golgi apparatus (B), have a cytosolic LR and extracellular QYFLYGF motif that interacts with ERp29 (yellow) and other putative chaperones (grey ovals) that stabilize monomeric connexins until they transition from the endoplasmic reticulum (ER) to the Golgi apparatus (delineated by the dashed lines). In the Golgi apparatus, ERp29 dissociates from monomeric connexins and then recycles back to the ER, enabling connexins to oligomerize into hexameric hemichannels. By contrast, connexins (such as Cx32) that have a WW and a FYxLYxG motif cannot interact with ERp29-they are inserted into the ER membrane as unstable monomers and thus immediately oligomerize (C). 
By contrast, beta connexins lack charged residues adjacent to the TM3 domain. They instead have a di-tryptophan (WW) motif that is less stringently localized to the membrane/cytosol interface, and they lack the ability to interact with ERp29. Thus, beta connexins are not stable as monomers and instead oligomerize in the ER (Figure 2) [300-302]. Since motifs associated with the TM3 domain also have been implicated in regulating connexin hetero-oligomerization [299,306], this implicates a role for spatial separation of connexin oligomerization in regulating the extent and stoichiometry of heteromeric channel formation.

\subsection{Connexin Quality Control}

The differences in quality control for $\mathrm{Cx} 26$ and $\mathrm{C} \times 43$ were directly observed for native connexins in human airway epithelial cells derived from a cystic fibrosis $(\mathrm{CF})$ patient expressing the $\mathrm{CF}$ transmembrane conductance regulator (CFTR) protein harboring the Fdel508 mutation [307]. In these cells, Cx43 trafficking and function is impaired, yet Cx26 transport and assembly into gap junction channels is normal. Interestingly, CFTR also interacts with ERp29 [308], and Cx43-mediated GJIC by Fdel508-CFTR-expressing cells is restored by treatment with 4-phenylbutyrate, a drug that upregulates ERp29 expression [307,308]. In addition, 4-phenylbutyrate has been shown to upregulate GJIC in several other contexts [309-314], further underscoring a role for ERp29 and other 4-phenylbutyrate-sensitive factors in connexin quality control.

Aberrant accumulation of connexins in the ER clearly decreases the pool of connexins available to produce gap junction channels at the cell surface. However, ER accumulation of connexins has also been found to induce an unfolded protein response (UPR) that, in turn, has the capacity to impair cell function and lead to human disease. UPR induced by mutant connexins has been directly demonstrated for Cx50 mutations associated with cataract [315-317] and Cx31 mutations that cause the skin disease erythrokeratoderma variabilis (EKV) [318] or hearing impairment [319]. The association of UPR with human diseases related to misfolded connexins suggests the possibility that treatments alleviating ER stress, such as 4-phenylbutyrate, may have therapeutic value by promoting proper protein folding and trafficking as well as increasing GJIC. Also, as mentioned above, the ability of 4-phenylbutyrate to enhance GJIC also may contribute to its potential as an anticancer therapeutic, and may be related to increased ERp29 activity [320].

\subsection{Connexin Cytoplasmic Domains and the Cytoskeleton}

In addition to motifs adjacent to the TM3 domain, there are several lines of evidence in support of connexin C-terminal domains in regulating connexin trafficking. As described above, in addition to containing several motifs that can be post-translationally modified, the semi-structured nature of the C-terminus $[153,155,321]$ enables it to be conformationally labile and to interact with several different classes of cytosolic scaffold proteins and the cytoskeleton that can influence connexin targeting (reviewed in [5] for Cx43). For instance, several truncated connexins lack the ability to be efficiently trafficked to the plasma membrane or be endocytosed [322,323]. The connexin C-terminal domains also have the capacity to homo- and hetero-dimerize $[153,155,159,324]$ as well as interact with other connexin domains, including the cytoplasmic loop $[155,325,326]$ that can influence connexin targeting, oligomerization, and function.

Interestingly, it was determined that there is reciprocal regulation of Cx43 and Cx46 in the lens, where conditions such as activation of PKC caused an increase in Cx46 transcription and expression that was associated with a concomitant decrease in Cx43, via ubiquitination and proteasomal degradation [327]. In fact, transfecting cells with Cx46 was sufficient to induce Cx43 degradation and this effect required the $\mathrm{C}$-terminus of $\mathrm{Cx} 46$, since a $\mathrm{Cx} 46$ tail truncation mutant had no effect on $\mathrm{Cx} 43$ expression. Increased Cx50 also had no effect on Cx43. However, transfecting cells with a soluble Cx46 tail construct had the ability to decrease $\mathrm{Cx} 43$ expression. Since the decrease in $\mathrm{C} \times 43$ was induced by an intracellular pool of $C \times 46$, this raises the possibility that crosstalk between $C \times 46$ and $C x 43$ may be related to differential oligomerization [304]. However, this remains to be determined. 
As another instance where the C-terminus plays a key role in regulating Cx43 trafficking, it has been shown that amino N-terminal truncated forms of $\mathrm{Cx} 43$ are also expressed by cells, through alternative internal translation via one of six different AUG initiation sites (see Section 2.4.2) [328]. The most prominent of these is GJA1-20k, which consists of a portion of the TM4 domain as well as the entire C-terminus [110] (Figure 1). GJA1-20k expression promotes formation of Cx43 gap junction channels, resulting in an increase in intercellular communication $[110,113]$. As discussed in Section 2.4.2, alternative translation of Cx43, including production of GJA1-20k, is inhibited by mTOR [110,111] and Mnk1/2 kinases [111], suggesting that metabolic stress regulates gap junctional coupling through mTOR- and Mnk1/2-mediated pathways as a means to protect cells both by enabling scarce metabolites to be distributed via intercellular communication as well as limiting damage by restricting generation of reactive oxygen species [329].

How GJA1-20k regulates channel formation by $\mathrm{Cx} 43$ is still under investigation. One intriguing possibility is that GJA1-20k acts as a chaperone protein that promotes $\mathrm{Cx} 43$ oligomerization, as was recently demonstrated to regulate the decrease in gap junction formation and function that can occur in the epithelial to mesenchyme transition [330] (Figure 1).

Another likely role for GJA1-20k relates to cytoskeletal control of Cx43 trafficking, since it has been shown that the C-terminus of Cx43 and, therefore, GJA-20k as well, interacts with both microtubules and filamentous actin [331-333]. Microtubules and actin perform complementary functions in regulating connexin trafficking, where microtubules help facilitate rapid transport of Cx43-containing vesicles to sites of junction formation [332], whereas actin has a more subtle role in regulating connexin trafficking, since quantitative live cell-imaging shows that transport of Cx43-containing vesicles temporarily pauses when they interact with actin filaments, perhaps as a means to enhance sorting or to remodel vesicle composition [331]. Also, transfecting HeLa cells with GJA1-20k nucleates the formation of actin filaments [113], suggesting a role for GJA1-20k in altering the itinerary of Cx43 trafficking in the cell. Reverse regulation is also suggested by studies where gap junction inhibitors resulted in misalignment of actin filaments across the monolayer and reduced calcium signaling in rat astrocytes [334]. Furthermore, treatment of astrocytes with an actin polymerization inhibitor cytochalasin D or anti-actin antibodies reduced GJIC, as visualized by a reduction in the spread of microinjected neurobiotin between cells [335].

\subsection{Regulation of Gap Junction Plaque Morphology}

Actin has also been implicated in regulating gap junction plaque morphology. Double knockout of the actin capping protein tropomodulin 1 and intermediate filament protein CP49 in lens fiber cells led to a significant decrease in Cx46 plaque volume and increase in plaque number, affecting gap junction coupling and function in the lens tissue [336]. Regulation of plaque size by actin is likely to be coordinated by interactions involving the C-terminus of connexins and zonula occludens 1 (ZO-1). For example, enhanced green fluorescent protein (EGFP)-tagged Cx43 incapable of interacting with ZO-1 produces plaques that are not size regulated [337]. By contrast, the perimeter of gap junction plaques (the perinexus) is ringed by $\mathrm{Cx} 43 / \mathrm{ZO}-1$ complexes, whereas the center of plaques is largely devoid of ZO-1 [338]. Inhibition of Cx43/ZO-1 interactions cause an increase in gap junction plaque size. Consistent with this possibility, Cx43 phosphorylation inhibits ZO-1 binding and facilitates connexin channel endocytosis [339]. Additional roles for ZO-1, connexin phosphorylation, and ubiquitinylation in regulating connexin endocytosis and degradation are described in Sections 3.2 and 3.3, above.

Although the precise mechanism whereby ZO-1 limits plaque formation is still under investigation, it seems plausible that it may be analogous to the role of ZO-1 in regulating tight junctions, where claudin/ZO-1/actin interactions have a junction-stabilizing influence on the apical junctional complex, whereas, in the absence of ZO-1, there is increased access of myosin that increases tight junction dynamics and tension [340,341]. Consistent with this possibility, myosin VI has also been found to have a specific role in increasing gap junction plaque size, analogous to treatments inhibiting Cx43/ZO-1 interactions [342]. 
Whether regulation of plaque assembly strictly follows the perinexus model has recently been challenged by observations of Cx36 plaque formation [343]. Pulse-chase experiments with Cx36 indicated addition of $\mathrm{C} \times 36$ to both the ends and the middle of preexisting gap junction plaques, with diffusion of Cx36 throughout the plaque. When the experiments were repeated with Cx43, there appeared to be less diffusion of newly added Cx43 in preexisting plaques [343]. Targeted delivery of connexins has only recently been observed. Through interactions with plus-end binding protein EB1 and the dynein/dynactin complex, microtubule plus-ends are tethered to adherens junctions at the plasma membrane, leading to the targeted deposition of connexin hemichannels and gap junction plaque formation [332]. These two models begin to bring to light the vast complexity of connexin trafficking and gap junction formation, suggesting a network of cytoskeleton and protein-binding partners tailored to specific connexins that was previously unrealized.

A less understood but intriguing role for the cytoskeleton in gap junction biology is the creation of unique junctional subregions involved in gap junction dynamics. Using an EGFP-tagged Cx32 construct, particularly dynamic regions at the edges of gap junction plaques were observed as invaginated tubular structures, where plaque fragments pinched off into the cytoplasm [344]. These tubulovesicular extensions of gap junction plaques were recently observed with Cx36 and termed filadendrites [345]. Filadendrites at the edges of gap junction plaques appeared to be the same thickness as the plaque, suggesting that the filadendrites were a continuation of the gap junction plaques themselves. Filadendrites were also observed in interior regions of the gap junction plaques, but appeared to be much thinner than the gap junction plaques. From pulse-chase labeling of $\mathrm{Cx} 36$, it was observed that filadendrites exhibited some of the same dynamic properties as the earlier observed Cx32 invaginations, constantly pinching off and fusing with the gap junction plaque. Labeling of actin filaments showed colocalization with Cx36 filadendrites, suggesting that the actin cytoskeleton could be one of the drivers behind the formation of these dynamic structures. Treatment with the actin polymerization inhibitor Latrunculin A or actin depolymerization inducer cytochalasin D reduced the presence of filadendrites, indicating that the driving force behind the dynamic gap junction plaques requires actin polymerization [345].

Similar structures have been noted at other junctions. Primary human keratinocytes treated with pemphigus vulgaris (PV) IgG containing antibodies targeted to the adherens junction protein desmoglein 3 (Dsg3) exhibited reorganized Dsg3 at the membrane into projections perpendicular to the membrane plane. These projections, termed linear arrays, are similar to the filadendrites in that they are sites of disassembly of junction components and active endocytosis at the junctions. Linear arrays also colocalized with actin filaments oriented perpendicular to the plasma membrane, similar to those observed in filadendrites. Furthermore, linear arrays were associated with decreased cell adhesion, suggesting a functional effect of these junctional subregions [346,347]. A comparable structure formed by tight junction proteins, termed tight junction spikes, have been observed to correlate with treatments that enhance junction disassembly and paracellular leak, including oxidative stress induced by chronic alcohol exposure, transforming growth factor (TGF)- $\beta 1$ treatment, and inhibition of NF-KB [348-350]. In alveolar epithelial cells, actin filaments colocalized with the tight junction protein claudin-18 in tight junction spikes. Spikes were also found to be sites of budding and fusion of vesicles carrying tight junction proteins, both indicators of active tight junction remodeling. Treatment of lung alveolar epithelial cells with granulocyte-macrophage colony-stimulating factor (GM-CSF) reduced actin filament colocalization with claudin-18 containing tight junction spikes, whereas keratinocyte growth factor treatment inhibited spike formation and instead promoted formation of cortical actin as opposed to actin stress fibers [350,351]. Taken together, these findings indicate that these similar junctional subregions observed universally across several different classes of intercellular junctions, including gap junctions, could represent a common mechanism of junction protein turnover, where the junctions partition themselves into unique filamentous structures. Whether these structures serve to restrict turnover of junction proteins to specific subdomains or whether they nucleate the formation of signaling complexes that recruit specialized subsets of cytosolic binding partners remains to be determined. 


\section{Conclusions and Future Perspectives}

In order to fully understand the complex role of connexins in health and disease, it is essential to elucidate their regulation at all steps, from gene transcription, protein synthesis, post-translational modifications, and trafficking to their regulation at the cell membrane. This review is intended to highlight some of the progress made in these areas in relation to health and disease, giving examples of how this knowledge is pertinent for future therapeutic applications. Going forward, understanding how modulation of connexins occurs at any of these stages will require additional work and insight, which over time may lead to more fruitful and safer strategies to alleviate patient suffering. For example, the danegaptide trials that were based on strong preclinical data suggested that alterations to the trafficking and increased Cx43 signaling in the heart would have a profound effect in reducing ischemic reperfusion injury and reduce cardiac tissue damage. However, Phase II clinical trials in humans failed to show an effect, highlighting the complex nature of targeting gap junctions as a treatment modality including differences in how connexins are regulated in model systems as opposed to human disease. Additional caution is also needed for therapeutic approaches in cancer, where it is now clear that connexins have distinct roles that both promote and inhibit cell growth and metastasis.

Despite substantial progress, it is important to acknowledge the complexity of gap junctions that serve as a conduit that enables cells to share thousands of different signaling molecules. Additionally, the complex connexin protein interactome underscores the non-junctional functions of connexins, including their ability to act as a signaling platform. In particular, it is critical to identify connexin-specific functions that are unique and targetable. This is best approached by understanding how connexins are regulated at multiple levels by multiple mechanisms, from gene transcription and translation to post-translational modification, and as a specifically localized multiprotein complex.

Acknowledgments: Trond Aasen acknowledges support from Instituto de Salud Carlos III grants PI13/00763, PI16/00772 and CPII16/00042, co-financed by the European Regional Development Fund (ERDF). Supported by NIH R01-AA025854 and R01-HL137112 (Michael Koval) and F31-HL139109 (K. Sabrina Lynn).

Conflicts of Interest: The authors declare no conflict of interest. The funding sponsors had no role in the design of the study; in the collection, analyses, or interpretation of data; in the writing of the manuscript, and in the decision to publish the results.

\section{References}

1. Goodenough, D.A.; Paul, D.L. Gap junctions. Cold Spring Harb. Perspect. Biol. 2009, 1, a002576. [CrossRef] [PubMed]

2. Esseltine, J.L.; Laird, D.W. Next-generation connexin and pannexin cell biology. Trends Cell Biol. 2016, 26, 944-955. [CrossRef] [PubMed]

3. Aasen, T.; Mesnil, M.; Naus, C.C.; Lampe, P.D.; Laird, D.W. Gap junctions and cancer: Communicating for 50 years. Nat. Rev. Cancer 2016, 16, 775-788. [CrossRef] [PubMed]

4. Saez, J.C.; Leybaert, L. Hunting for connexin hemichannels. FEBS Lett. 2014, 588, 1205-1211. [CrossRef] [PubMed]

5. Leithe, E.; Mesnil, M.; Aasen, T. The connexin 43 C-terminus: A tail of many tales. Biochim. Biophys. Acta 2018, 1860, 48-64. [CrossRef] [PubMed]

6. Delmar, M.; Laird, D.W.; Naus, C.C.; Nielsen, M.S.; Verselis, V.K.; White, T.W. Connexins and disease. Cold Spring Harb. Perspect. Biol. 2017. [CrossRef] [PubMed]

7. Srinivas, M.; Verselis, V.K.; White, T.W. Human diseases associated with connexin mutations. Biochim. Biophys. Acta 2018, 1860, 192-201. [CrossRef] [PubMed]

8. Kelly, J.J.; Simek, J.; Laird, D.W. Mechanisms linking connexin mutations to human diseases. Cell Tissue Res. 2015, 360, 701-721. [CrossRef] [PubMed]

9. Aasen, T. Connexins: Junctional and non-junctional modulators of proliferation. Cell Tissue Res. 2015, 360, 685-699. [CrossRef] [PubMed] 
10. Leybaert, L.; Lampe, P.D.; Dhein, S.; Kwak, B.R.; Ferdinandy, P.; Beyer, E.C.; Laird, D.W.; Naus, C.C.; Green, C.R.; Schulz, R. Connexins in cardiovascular and neurovascular health and disease: Pharmacological implications. Pharmacol. Rev. 2017, 69, 396-478. [CrossRef] [PubMed]

11. Becker, D.L.; Phillips, A.R.; Duft, B.J.; Kim, Y.; Green, C.R. Translating connexin biology into therapeutics. Semin. Cell Dev. Biol. 2016, 50, 49-58. [CrossRef] [PubMed]

12. Grek, C.L.; Rhett, J.M.; Ghatnekar, G.S. Cardiac to cancer: Connecting connexins to clinical opportunity. FEBS Lett. 2014, 588, 1349-1364. [CrossRef] [PubMed]

13. Lee, C.; Huang, C.H. Lasagna-search: An integrated web tool for transcription factor binding site search and visualization. BioTechniques 2013, 54, 141-153. [CrossRef] [PubMed]

14. Söhl, G.; Willecke, K. An update on connexin genes and their nomenclature in mouse and man. Cell Commun. Adhes. 2003, 10, 173-180. [CrossRef] [PubMed]

15. Beyer, E.C.; Berthoud, V.M. Gap junction gene and protein families: Connexins, innexins, and pannexins. Biochim. Biophys. Acta 2018, 1860, 5-8. [CrossRef] [PubMed]

16. Dupays, L.; Mazurais, D.; Rücker-Martin, C.; Calmels, T.; Bernot, D.; Cronier, L.; Malassiné, A.; Gros, D.; Théveniau-Ruissy, M. Genomic organization and alternative transcripts of the human connexin 40 gene. Gene 2003, 305, 79-90. [CrossRef]

17. Essenfelder, G.M.; Larderet, G.; Waksman, G.; Lamartine, J. Gene structure and promoter analysis of the human gjb6 gene encoding connexin30. Gene 2005, 350, 33-40. [CrossRef] [PubMed]

18. Sohl, G.; Theis, M.; Hallas, G.; Brambach, S.; Dahl, E.; Kidder, G.; Willecke, K. A new alternatively spliced transcript of the mouse connexin32 gene is expressed in embryonic stem cells, oocytes, and liver. Exp. Cell Res. 2001, 266, 177-186. [CrossRef] [PubMed]

19. Pfeifer, I.; Anderson, C.; Werner, R.; Oltra, E. Redefining the structure of the mouse connexin 43 gene: Selective promoter usage and alternative splicing mechanisms yield transcripts with different translational efficiencies. Nucleic Acids Res. 2004, 32, 4550-4562. [CrossRef] [PubMed]

20. Anderson, C.L.; Zundel, M.A.; Werner, R. Variable promoter usage and alternative splicing in five mouse connexin genes. Genomics 2005, 85, 238-244. [CrossRef] [PubMed]

21. Cicirata, F.; Parenti, R.; Spinella, F.; Giglio, S.; Tuorto, F.; Zuffardi, O.; Gulisano, M. Genomic organization and chromosomal localization of the mouse connexin36 ( $m C x 36)$ gene. Gene 2000, 251, 123-130. [CrossRef]

22. Von Maltzahn, J.; Euwens, C.; Willecke, K.; Söhl, G. The novel mouse connexin39 gene is expressed in developing striated muscle fibers. J. Cell Sci. 2004, 117, 5381-5392. [CrossRef] [PubMed]

23. Hombach, S.; Janssen-Bienhold, U.; Sohl, G.; Schubert, T.; Bussow, H.; Ott, T.; Weiler, R.; Willecke, K. Functional expression of connexin57 in horizontal cells of the mouse retina. Eur. J. Neurosci. 2004, 19, 2633-2640. [CrossRef] [PubMed]

24. Söhl, G.; Joussen, A.; Kociok, N.; Willecke, K. Expression of connexin genes in the human retina. BMC Ophthalmol. 2010, 10, 27. [CrossRef] [PubMed]

25. Oyamada, M.; Takebe, K.; Oyamada, Y. Regulation of connexin expression by transcription factors and epigenetic mechanisms. Biochim. Biophys. Acta Biomembr. 2013, 1828, 118-133. [CrossRef] [PubMed]

26. Neuhaus, I.M.; Bone, L.; Wang, S.; Ionasescu, V.; Werner, R. The human connexin 32 gene is transcribed from two tissue-specific promoters. Biosci. Rep. 1996, 16, 239-248. [CrossRef] [PubMed]

27. Murphy, S.M.; Polke, J.; Manji, H.; Blake, J.; Reiniger, L.; Sweeney, M.; Houlden, H.; Brandner, S.; Reilly, M.M. A novel mutation in the nerve-specific 5' UTR of the GJB1 gene causes X-linked charcot-marie-tooth disease. J. Peripher. Nerv. Syst. JPNS 2011, 16, 65-70. [CrossRef] [PubMed]

28. Kulshrestha, R.; Burton-Jones, S.; Antoniadi, T.; Rogers, M.; Jaunmuktane, Z.; Brandner, S.; Kiely, N.; Manuel, R.; Willis, T. Deletion of $\mathrm{p} 2$ promoter of GJB1 gene a cause of charcot-marie-tooth disease. Neuromuscul. Disord. NMD 2017, 27, 766-770. [CrossRef] [PubMed]

29. Al-Yahyaee, S.A.; Al-Kindi, M.; Jonghe, P.D.; Al-Asmi, A.; Al-Futaisi, A.; Vriendt, E.D.; Deconinck, T.; Chand, P. Pelizaeus-merzbacher-like disease in a family with variable phenotype and a novel splicing GJC2 mutation. J. Child Neurol. 2013, 28, 1467-1473. [CrossRef] [PubMed]

30. Gandia, M.; Del Castillo, F.J.; Rodriguez-Alvarez, F.J.; Garrido, G.; Villamar, M.; Calderon, M.; Moreno-Pelayo, M.A.; Moreno, F.; del Castillo, I. A novel splice-site mutation in the GJB2 gene causing mild postlingual hearing impairment. PLoS ONE 2013, 8, e73566. [CrossRef] [PubMed]

31. Kandouz, M.; Bier, A.; Carystinos, G.D.; Alaoui-Jamali, M.A.; Batist, G. Connexin43 pseudogene is expressed in tumor cells and inhibits growth. Oncogene 2004, 23, 4763-4770. [CrossRef] [PubMed] 
32. Bier, A.; Oviedo-Landaverde, I.; Zhao, J.; Mamane, Y.; Kandouz, M.; Batist, G. Connexin43 pseudogene in breast cancer cells offers a novel therapeutic target. Mol. Cancer Ther. 2009, 8, 786-793. [CrossRef] [PubMed]

33. Hong, H.M.; Yang, J.J.; Shieh, J.C.; Lin, M.L.; Li, S.Y. Novel mutations in the connexin43 (GJA1) and GJA1 pseudogene may contribute to nonsyndromic hearing loss. Hum. Genet. 2010, 127, 545-551. [CrossRef] [PubMed]

34. Poliseno, L.; Salmena, L.; Zhang, J.; Carver, B.; Haveman, W.J.; Pandolfi, P.P. A coding-independent function of gene and pseudogene mRNAs regulates tumour biology. Nature 2010, 465, 1033-1038. [CrossRef] [PubMed]

35. Rackauskas, M.; Neverauskas, V.; Skeberdis, V.A. Diversity and properties of connexin gap junction channels (review). Medicina (Kaunas Lithuania) 2010, 46, 1-12. [PubMed]

36. Di, W.L.; Rugg, E.L.; Leigh, I.M.; Kelsell, D.P. Multiple epidermal connexins are expressed in different keratinocyte subpopulations including connexin 31. J. Investig. Dermatol. 2001, 117, 958-964. [CrossRef] [PubMed]

37. Scott, C.A.; Tattersall, D.; O'Toole, E.A.; Kelsell, D.P. Connexins in epidermal homeostasis and skin disease. Biochim. Biophys. Acta 2012, 1818, 1952-1961. [CrossRef] [PubMed]

38. Faniku, C.; Wright, C.S.; Martin, P.E. Connexins and pannexins in the integumentary system: The skin and appendages. Cell. Mol. Life Sci. CMLS 2015, 72, 2937-2947. [CrossRef] [PubMed]

39. Lilly, E.; Sellitto, C.; Milstone, L.M.; White, T.W. Connexin channels in congenital skin disorders. Semin. Cell Dev. Biol. 2016, 50, 4-12. [CrossRef] [PubMed]

40. Tu, Z.J.; Kiang, D.T. Mapping and characterization of the basal promoter of the human connexin26 gene. Biochim. Biophys. Acta 1998, 1443, 169-181. [CrossRef]

41. Bai, S.; Spray, D.C.; Burk, R.D. Identification of proximal and distal regulatory elements of the rat connexin32 gene. BBA Gene Struct. Expr. 1993, 1216, 197-204. [CrossRef]

42. Field, J.M.L.; Tate, L.A.; Chipman, J.K.; Minchin, S.D. Identification of functional regulatory regions of the connexin32 gene promoter. Biochim. Biophys. Acta Gene Struct. Expr. 2003, 1628, 22-29. [CrossRef]

43. Seul, K.H.; Tadros, P.N.; Beyer, E.C. Mouse connexin40: Gene structure and promoter analysis. Genomics 1997, 46, 120-126. [CrossRef] [PubMed]

44. Bierhuizen, M.F.A.; Van Amersfoorth, S.C.M.; Groenewegen, W.A.; Vliex, S.; Jongsma, H.J. Characterization of the rat connexin40 promoter: Two Sp1/Sp3 binding sites contribute to transcriptional activation. Cardiovasc. Res. 2000, 46, 511-522. [CrossRef]

45. Echetebu, C.O.; Ali, M.; Izban, M.G.; MacKay, L.; Garfield, R.E. Localization of regulatory protein binding sites in the proximal region of human myometrial connexin 43 gene. Mol. Hum. Reprod. 1999, 5, 757-766. [CrossRef] [PubMed]

46. Teunissen, B.E.J.; van Amersfoorth, S.C.M.; Opthof, T.; Jongsma, H.J.; Bierhuizen, M.F.A. Sp1 and Sp3 activate the rat connexin40 proximal promoter. Biochem. Biophys. Res. Commun. 2002, 292, 71-78. [CrossRef] [PubMed]

47. Linhares, V.L.F.; Almeida, N.A.S.; Menezes, D.C.; Elliott, D.A.; Lai, D.; Beyer, E.C.; Campos De Carvalho, A.C.; Costa, M.W. Transcriptional regulation of the murine connexin 40 promoter by cardiac factors nkx2-5, gata4 and tbx5. Cardiovasc. Res. 2004, 64, 402-411. [CrossRef] [PubMed]

48. Geimonen, E.; Boylston, E.; Royek, A.; Andersen, J. Elevated connexin-43 expression in term human myometrium correlates with elevated C-jun expression and is independent of myometrial estrogen receptors. J. Clin. Endocrinol. Metab. 1998, 83, 1177-1185. [CrossRef] [PubMed]

49. Fernandez-Cobo, M.; Stewart, D.; Drujan, D.; De Maio, A. Promoter activity of the rat connexin 43 gene in nrk cells. J. Cell. Biochem. 2001, 81, 514-522. [CrossRef]

50. Teunissen, B.E.J.; Jansen, A.T.; Van Amersfoorth, S.C.M.; O’Brien, T.X.; Jongsma, H.J.; Bierhuizen, M.F.A. Analysis of the rat connexin 43 proximal promoter in neonatal cardiomyocytes. Gene 2003, 322, 123-136. [CrossRef] [PubMed]

51. Vine, A.L.; Leung, Y.M.; Bertram, J.S. Transcriptional regulation of connexin 43 expression by retinoids and carotenoids: Similarities and differences. Mol. Carcinog. 2005, 43, 75-85. [CrossRef] [PubMed]

52. Hernandez, M.; Shao, Q.; Yang, X.J.; Luh, S.P.; Kandouz, M.; Batist, G.; Laird, D.W.; Alaoui-Jamali, M.A. A histone deacetylation-dependent mechanism for transcriptional repression of the gap junction gene $c \times 43$ in prostate cancer cells. Prostate 2006, 66, 1151-1161. [CrossRef] [PubMed]

53. Villares, G.J.; Dobroff, A.S.; Wang, H.; Zigler, M.; Melnikova, V.O.; Huang, L.; Bar-Eli, M. Overexpression of protease-activated receptor-1 contributes to melanoma metastasis via regulation of connexin 43 . Cancer Res. 2009, 69, 6730-6737. [CrossRef] [PubMed] 
54. Geimonen, E.; Jiang, W.; Ali, M.; Fishman, G.I.; Garfield, R.E.; Andersen, J. Activation of protein kinase c in human uterine smooth muscle induces connexin-43 gene transcription through an AP-1 site in the promoter sequence. J. Biol. Chem. 1996, 271, 23667-23674. [CrossRef] [PubMed]

55. Ghouili, F.; Martin, L.J. Cooperative regulation of GJA1 expression by members of the AP-1 family cjun and cfos in TM3 leydig and TM4 sertoli cells. Gene 2017, 635, 24-32. [CrossRef] [PubMed]

56. Baldridge, D.; Lecanda, F.; Shin, C.S.; Stains, J.; Civitelli, R. Sequence and structure of the mouse connexin 45 gene. Biosci. Rep. 2001, 21, 683-689. [CrossRef] [PubMed]

57. Van der Heyden, M.A.; Rook, M.B.; Hermans, M.M.; Rijksen, G.; Boonstra, J.; Defize, L.H.; Destree, O.H. Identification of connexin43 as a functional target for Wnt signalling. J. Cell Sci. 1998, 111 Pt 12, 1741-1749. [PubMed]

58. Ai, Z.; Fischer, A.; Spray, D.C.; Brown, A.M.; Fishman, G.I. Wnt-1 regulation of connexin43 in cardiac myocytes. J. Clin. Investig. 2000, 105, 161-171. [CrossRef] [PubMed]

59. Teunissen, B.E.; Bierhuizen, M.F. Transcriptional control of myocardial connexins. Cardiovasc. Res. 2004, 62, 246-255. [CrossRef] [PubMed]

60. Koffler, L.D.; Fernstrom, M.J.; Akiyama, T.E.; Gonzalez, F.J.; Ruch, R.J. Positive regulation of connexin32 transcription by hepatocyte nuclear factor-1 $\alpha$. Arch. Biochem. Biophys. 2002, 407, 160-167. [CrossRef]

61. Rukstalis, J.M.; Kowalik, A.; Zhu, L.; Lidington, D.; Pin, C.L.; Konieczny, S.F. Exocrine specific expression of connexin32 is dependent on the basic helix-loop-helix transcription factor mist1. J. Cell Sci. 2003, 116, 3315-3325. [CrossRef] [PubMed]

62. Bondurand, N.; Girard, M.; Pingault, V.; Lemort, N.; Dubourg, O.; Goossens, M. Human connexin 32, a gap junction protein altered in the X-linked form of charcot-marie-tooth disease, is directly regulated by the transcription factor SOX10. Hum. Mol. Genet. 2001, 10, 2783-2795. [CrossRef] [PubMed]

63. Petrocelli, T.; Lye, S.J. Regulation of transcripts encoding the myometrial gap junction protein, connexin-43, by estrogen and progesterone. Endocrinology 1993, 133, 284-290. [CrossRef] [PubMed]

64. Recouvreux, M.S.; Grasso, E.N.; Echeverria, P.C.; Rocha-Viegas, L.; Castilla, L.H.; Schere-Levy, C.; Tocci, J.M.; Kordon, E.C.; Rubinstein, N. RUNX1 and FOXP3 interplay regulates expression of breast cancer related genes. Oncotarget 2016, 7, 6552-6565. [CrossRef] [PubMed]

65. Vinken, M. Regulation of connexin signaling by the epigenetic machinery. Biochim. Biophys. Acta 2015, 1859, 262-268. [CrossRef] [PubMed]

66. Chen, Y.; Huhn, D.; Knosel, T.; Pacyna-Gengelbach, M.; Deutschmann, N.; Petersen, I. Downregulation of connexin 26 in human lung cancer is related to promoter methylation. Int. J. Cancer 2005, 113, 14-21. [CrossRef] [PubMed]

67. Tan, L.W.; Bianco, T.; Dobrovic, A. Variable promoter region cpg island methylation of the putative tumor suppressor gene connexin 26 in breast cancer. Carcinogenesis 2002, 23, 231-236. [CrossRef] [PubMed]

68. Hirai, A.; Yano, T.; Nishikawa, K.; Suzuki, K.; Asano, R.; Satoh, H.; Hagiwara, K.; Yamasaki, H. Down-regulation of connexin 32 gene expression through DNA methylation in a human renal cell carcinoma cell. Am. J. Nephrol. 2003, 23, 172-177. [CrossRef] [PubMed]

69. Chen, J.T.; Cheng, Y.W.; Chou, M.C.; Sen-Lin, T.; Lai, W.W.; Ho, W.L.; Lee, H. The correlation between aberrant connexin 43 mRNA expression induced by promoter methylation and nodal micrometastasis in non-small cell lung cancer. Clin. Cancer Res. 2003, 9, 4200-4204. [PubMed]

70. Wang, Y.; Huang, L.H.; Xu, C.X.; Xiao, J.; Zhou, L.; Cao, D.; Liu, X.M.; Qi, Y. Connexin 32 and 43 promoter methylation in helicobacter pylori-associated gastric tumorigenesis. World J. Gastroenterol. WJG 2014, 20, 11770-11779. [CrossRef] [PubMed]

71. Yi, Z.C.; Wang, H.; Zhang, G.Y.; Xia, B. Downregulation of connexin 43 in nasopharyngeal carcinoma cells is related to promoter methylation. Oral Oncol. 2007, 43, 898-904. [CrossRef] [PubMed]

72. Sirnes, S.; Honne, H.; Ahmed, D.; Danielsen, S.A.; Rognum, T.O.; Meling, G.I.; Leithe, E.; Rivedal, E.; Lothe, R.A.; Lind, G.E. DNA methylation analyses of the connexin gene family reveal silencing of GJC1 (connexin45) by promoter hypermethylation in colorectal cancer. Epigenetics 2011, 6, 602-609. [CrossRef] [PubMed]

73. Ogawa, T.; Hayashi, T.; Tokunou, M.; Nakachi, K.; Trosko, J.E.; Chang, C.C.; Yorioka, N. Suberoylanilide hydroxamic acid enhances gap junctional intercellular communication via acetylation of histone containing connexin 43 gene locus. Cancer Res. 2005, 65, 9771-9778. [CrossRef] [PubMed] 
74. Xu, Q.; Lin, X.; Andrews, L.; Patel, D.; Lampe, P.D.; Veenstra, R.D. Histone deacetylase inhibition reduces cardiac connexin43 expression and gap junction communication. Front. Pharmacol. 2013, 4, 44. [CrossRef] [PubMed]

75. Zhao, W.; Han, H.B.; Zhang, Z.Q. Suppression of lung cancer cell invasion and metastasis by connexin 43 involves the secretion of follistatin-like 1 mediated via histone acetylation. Int. J. Biochem. Cell Biol. 2011, 43, 1459-1468. [CrossRef] [PubMed]

76. Hohl, M.; Thiel, G. Cell type-specific regulation of RE-1 silencing transcription factor (REST) target genes. Eur. J. Neurosci. 2005, 22, 2216-2230. [CrossRef] [PubMed]

77. Colussi, C.; Rosati, J.; Straino, S.; Spallotta, F.; Berni, R.; Stilli, D.; Rossi, S.; Musso, E.; Macchi, E.; Mai, A.; et al. Nepsilon-lysine acetylation determines dissociation from gap junctions and lateralization of connexin 43 in normal and dystrophic heart. Proc. Natl. Acad. Sci. USA 2011, 108, 2795-2800. [CrossRef] [PubMed]

78. Colussi, C.; Berni, R.; Rosati, J.; Straino, S.; Vitale, S.; Spallotta, F.; Baruffi, S.; Bocchi, L.; Delucchi, F.; Rossi, S.; et al. The histone deacetylase inhibitor suberoylanilide hydroxamic acid reduces cardiac arrhythmias in dystrophic mice. Cardiovasc. Res. 2010, 87, 73-82. [CrossRef] [PubMed]

79. Forster, T.; Rausch, V.; Zhang, Y.; Isayev, O.; Heilmann, K.; Schoensiegel, F.; Liu, L.; Nessling, M.; Richter, K.; Labsch, S.; et al. Sulforaphane counteracts aggressiveness of pancreatic cancer driven by dysregulated CX43-mediated gap junctional intercellular communication. Oncotarget 2014, 5, 1621-1634. [CrossRef] [PubMed]

80. Salat-Canela, C.; Munoz, M.J.; Sese, M.; Ramon y Cajal, S.; Aasen, T. Post-transcriptional regulation of connexins. Biochem. Soc. Trans. 2015, 43, 465-470. [CrossRef] [PubMed]

81. Ming, J.; Zhou, Y.; Du, J.; Fan, S.; Pan, B.; Wang, Y.; Fan, L.; Jiang, J. Identification of miR-200a as a novel suppressor of connexin 43 in breast cancer cells. Biosci. Rep. 2015, 35. [CrossRef] [PubMed]

82. Li, X.; Pan, J.H.; Song, B.; Xiong, E.Q.; Chen, Z.W.; Zhou, Z.S.; Su, Y.P. Suppression of CX43 expression by miR-20a in the progression of human prostate cancer. Cancer Biol. Ther. 2012, 13, 890-898. [CrossRef] [PubMed]

83. Hao, J.; Zhang, C.; Zhang, A.; Wang, K.; Jia, Z.; Wang, G.; Han, L.; Kang, C.; Pu, P. MiR-221/222 is the regulator of CX43 expression in human glioblastoma cells. Oncol. Rep. 2012, 27, 1504-1510. [CrossRef] [PubMed]

84. Anderson, C.; Catoe, H.; Werner, R. MiR-206 regulates connexin43 expression during skeletal muscle development. Nucleic Acids Res. 2006, 34, 5863-5871. [CrossRef] [PubMed]

85. Hak, K.K.; Yong, S.L.; Sivaprasad, U.; Malhotra, A.; Dutta, A. Muscle-specific microRNA miR-206 promotes muscle differentiation. J. Cell Biol. 2006, 174, 677-687. [CrossRef]

86. Yang, B.; Lin, H.; Xiao, J.; Lu, Y.; Luo, X.; Li, B.; Zhang, Y.; Xu, C.; Bai, Y.; Wang, H.; et al. The muscle-specific microRNA miR-1 regulates cardiac arrhythmogenic potential by targeting GJA1 and KCNJ2. Nat. Med. 2007, 13, 486-491. [CrossRef] [PubMed]

87. Rau, F.; Freyermuth, F.; Fugier, C.; Villemin, J.P.; Fischer, M.C.; Jost, B.; Dembele, D.; Gourdon, G.; Nicole, A.; Duboc, D.; et al. Misregulation of miR-1 processing is associated with heart defects in myotonic dystrophy. Nat. Struct. Mol. Biol. 2011, 18, 840-845. [CrossRef] [PubMed]

88. Wu, Y.; Ma, X.J.; Wang, H.J.; Li, W.C.; Chen, L.; Ma, D.; Huang, G.Y. Expression of CX43-related microRNAs in patients with tetralogy of fallot. World J. Pediatr. WJP 2014, 10, 138-144. [CrossRef] [PubMed]

89. Imamura, M.; Sugino, Y.; Long, X.; Slivano, O.J.; Nishikawa, N.; Yoshimura, N.; Miano, J.M. Myocardin and microRNA-1 modulate bladder activity through connexin 43 expression during post-natal development. J. Cell. Physiol. 2013, 228, 1819-1826. [CrossRef] [PubMed]

90. Donahue, H.J.; Qu, R.W.; Genetos, D.C. Joint diseases: From connexins to gap junctions. Nat. Rev. Rheumatol. 2017, 14, 42-51. [CrossRef] [PubMed]

91. Gindin, Y.; Jiang, Y.; Francis, P.; Walker, R.L.; Abaan, O.D.; Zhu, Y.J.; Meltzer, P.S. MiR-23a impairs bone differentiation in osteosarcoma via down-regulation of GJA1. Front. Genet. 2015, 6, 233. [CrossRef] [PubMed]

92. Sun, Y.X.; Zhang, J.F.; Xu, J.; Xu, L.L.; Wu, T.Y.; Wang, B.; Pan, X.H.; Li, G. MicroRNA-144-3p inhibits bone formation in distraction osteogenesis through targeting connexin 43. Oncotarget 2017, 8, 89913-89922. [CrossRef] [PubMed]

93. Davis, H.M.; Pacheco-Costa, R.; Atkinson, E.G.; Brun, L.R.; Gortazar, A.R.; Harris, J.; Hiasa, M.; Bolarinwa, S.A.; Yoneda, T.; Ivan, M.; et al. Disruption of the CX43/miR21 pathway leads to osteocyte apoptosis and increased osteoclastogenesis with aging. Aging Cell 2017, 16, 551-563. [CrossRef] [PubMed]

94. Plotkin, L.I.; Pacheco-Costa, R.; Davis, H.M. MicroRNAs and connexins in bone: Interaction and mechanisms of delivery. Curr. Mol. Biol. Rep. 2017, 3, 63-70. [CrossRef] [PubMed] 
95. Ale-Agha, N.; Galban, S.; Sobieroy, C.; Abdelmohsen, K.; Gorospe, M.; Sies, H.; Klotz, L.O. Hur regulates gap junctional intercellular communication by controlling $\beta$-catenin levels and adherens junction integrity. Hepatology 2009, 50, 1567-1576. [CrossRef] [PubMed]

96. Lee, K.W.; Chun, K.S.; Lee, J.S.; Kang, K.S.; Surh, Y.J.; Lee, H.J. Inhibition of cyclooxygenase-2 expression and restoration of gap junction intercellular communication in h-ras-transformed rat liver epithelial cells by caffeic acid phenethyl ester. Ann. N. Y. Acad. Sci. 2004, 1030, 501-507. [CrossRef] [PubMed]

97. Ul-Hussain, M.; Dermietzel, R.; Zoidl, G. Connexins and cap-independent translation: Role of internal ribosome entry sites. Brain Res. 2012, 1487, 99-106. [CrossRef] [PubMed]

98. Werner, R. IRES elements in connexin genes: A hypothesis explaining the need for connexins to be regulated at the translational level. IUBMB Life 2000, 50, 173-176. [CrossRef] [PubMed]

99. Schiavi, A.; Hudder, A.; Werner, R. Connexin 43 mRNA contains a functional internal ribosome entry site. FEBS Lett. 1999, 464, 118-122. [CrossRef]

100. Hudder, A.; Werner, R. Analysis of a charcot-marie-tooth disease mutation reveals an essential internal ribosome entry site element in the connexin-32 gene. J. Biol. Chem. 2000, 275, 34586-34591. [CrossRef] [PubMed]

101. Lahlou, H.; Fanjul, M.; Pradayrol, L.; Susini, C.; Pyronnet, S. Restoration of functional gap junctions through internal ribosome entry site-dependent synthesis of endogenous connexins in density-inhibited cancer cells. Mol. Cell. Biol. 2005, 25, 4034-4045. [CrossRef] [PubMed]

102. Martinez-Salas, E.; Lozano, G.; Fernandez-Chamorro, J.; Francisco-Velilla, R.; Galan, A.; Diaz, R. RNA-binding proteins impacting on internal initiation of translation. Int. J. Mol. Sci. 2013, 14, 21705-21726. [CrossRef] [PubMed]

103. Faye, M.D.; Holcik, M. The role of IRES trans-acting factors in carcinogenesis. Biochim. Biophys. Acta 2015, 1849, 887-897. [CrossRef] [PubMed]

104. Komar, A.A.; Mazumder, B.; Merrick, W.C. A new framework for understanding IRES-mediated translation. Gene 2012, 502, 75-86. [CrossRef] [PubMed]

105. Thompson, S.R. So you want to know if your message has an IRES? Wiley Interdiscip. Rev. RNA 2012, 3, 697-705. [CrossRef] [PubMed]

106. Lauring, A.S.; Overbaugh, J. Evidence that an IRES within the Notch2 coding region can direct expression of a nuclear form of the protein. Mol. Cell 2000, 6, 939-945. [CrossRef]

107. Ul-Hussain, M.; Zoidl, G.; Klooster, J.; Kamermans, M.; Dermietzel, R. IRES-mediated translation of the carboxy-terminal domain of the horizontal cell specific connexin CX55.5 in vivo and in vitro. BMC Mol. Biol. 2008, 9, 52. [CrossRef] [PubMed]

108. Ul-Hussain, M.; Dermietzel, R.; Zoidl, G. Characterization of the internal IRES element of the zebrafish connexin55.5 reveals functional implication of the polypyrimidine tract binding protein. BMC Mol. Biol. 2008, 9, 92. [CrossRef] [PubMed]

109. Joshi-Mukherjee, R.; Coombs, W.; Burrer, C.; de Mora, I.A.; Delmar, M.; Taffet, S.M. Evidence for the presence of a free C-terminal fragment of cx43 in cultured cells. Cell Commun. Adhes. 2007, 14, 75-84. [CrossRef] [PubMed]

110. Smyth, J.W.; Shaw, R.M. Autoregulation of connexin43 gap junction formation by internally translated isoforms. Cell Rep. 2013, 5, 611-618. [CrossRef] [PubMed]

111. Salat-Canela, C.; Sese, M.; Peula, C.; Ramon y Cajal, S.; Aasen, T. Internal translation of the connexin 43 transcript. Cell Commun. Signal. 2014, 12, 31. [CrossRef] [PubMed]

112. Ul-Hussain, M.; Olk, S.; Schoenebeck, B.; Wasielewski, B.; Meier, C.; Prochnow, N.; May, C.; Galozzi, S.; Marcus, K.; Zoidl, G.; et al. Internal ribosomal entry site (IRES) activity generates endogenous carboxyl-terminal domains of CX43 and is responsive to hypoxic conditions. J. Biol. Chem. 2014, 289, 20979-20990. [CrossRef] [PubMed]

113. Basheer, W.A.; Xiao, S.; Epifantseva, I.; Fu, Y.; Kleber, A.G.; Hong, T.; Shaw, R.M. GJA1-20k arranges actin to guide CX43 delivery to cardiac intercalated discs. Circ. Res. 2017, 121, 1069-1080. [CrossRef] [PubMed]

114. Fu, Y.; Zhang, S.S.; Xiao, S.; Basheer, W.A.; Baum, R.; Epifantseva, I.; Hong, T.; Shaw, R.M. Cx43 isoform GJA1-20k promotes microtubule dependent mitochondrial transport. Front. Physiol. 2017, 8, 905. [CrossRef] [PubMed]

115. Maqbool, R.; Rashid, R.; Ismail, R.; Niaz, S.; Chowdri, N.A.; Hussain, M.U. The carboxy-terminal domain of connexin 43 (CT-CX43) modulates the expression of p53 by altering miR-125b expression in low-grade human breast cancers. Cell. Oncol. 2015, 38, 443-451. [CrossRef] [PubMed] 
116. Foote, C.I.; Zhou, L.; Zhu, X.; Nicholson, B.J. The pattern of disulfide linkages in the extracellular loop regions of connexin 32 suggests a model for the docking interface of gap junctions. J. Cell Biol. 1998, 140, 1187-1197. [CrossRef] [PubMed]

117. Johnstone, S.R.; Billaud, M.; Lohman, A.W.; Taddeo, E.P.; Isakson, B.E. Posttranslational modifications in connexins and pannexins. J. Membr. Biol. 2012, 245, 319-332. [CrossRef] [PubMed]

118. Solan, J.L.; Lampe, P.D. Specific Cx43 phosphorylation events regulate gap junction turnover in vivo. FEBS Lett. 2014, 588, 1423-1429. [CrossRef] [PubMed]

119. Pogoda, K.; Kameritsch, P.; Retamal, M.A.; Vega, J.L. Regulation of gap junction channels and hemichannels by phosphorylation and redox changes: A revision. BMC Cell Biol. 2016, 17 (Suppl. 1), 11. [CrossRef] [PubMed]

120. Lampe, P.D.; Lau, A.F. The effects of connexin phosphorylation on gap junctional communication. Int. J. Biochem. Cell Biol. 2004, 36, 1171-1186. [CrossRef]

121. Solan, J.L.; Lampe, P.D. Connexin phosphorylation as a regulatory event linked to gap junction channel assembly. Biochim. Biophys. Acta 2005, 1711, 154-163. [CrossRef] [PubMed]

122. Saez, J.C.; Martinez, A.D.; Branes, M.C.; Gonzalez, H.E. Regulation of gap junctions by protein phosphorylation. Braz. J. Med. Biol. Res. 1998, 31, 593-600. [CrossRef] [PubMed]

123. Stultz, C.M.; Levin, A.D.; Edelman, E.R. Phosphorylation-induced conformational changes in a mitogen-activated protein kinase substrate. Implications for tyrosine hydroxylase activation. J. Biol. Chem. 2002, 277, 47653-47661. [CrossRef] [PubMed]

124. Diestel, S.; Eckert, R.; Hülser, D.; Traub, O. Exchange of serine residues 263 and 266 reduces the function of mouse gap junction protein connexin 31 and exhibits a dominant-negative effect on the wild-type protein in hela cells. Exp. Cell Res. 2004, 294, 446-457. [CrossRef] [PubMed]

125. Qin, J.; Chang, M.; Wang, S.; Liu, Z.; Zhu, W.; Wang, Y.; Yan, F.; Li, J.; Zhang, B.; Dou, G.; et al. Connexin 32-mediated cell-cell communication is essential for hepatic differentiation from human embryonic stem cells. Sci. Rep. 2016, 6, 37388. [CrossRef] [PubMed]

126. Ghosh, P.; Ghosh, S.; Das, S. Self-regulation of rat liver gap junction by phosphorylation. Biochim. Biophys. Acta 2002, 1564, 500-504. [CrossRef]

127. Ghosh, P. Self-phosphorylation modulates the gating of rat liver gap junction channels: A nonstationary noise analysis. Biophys. Chem. 2007, 127, 97-102. [CrossRef] [PubMed]

128. Jacobsen, N.L.; Pontifex, T.K.; Li, H.; Solan, J.L.; Lampe, P.D.; Sorgen, P.L.; Burt, J.M. Regulation of cx37 channel and growth-suppressive properties by phosphorylation. J. Cell Sci. 2017, 130, 3308-3321. [CrossRef] [PubMed]

129. Bao, M.; Kanter, E.M.; Huang, R.Y.; Maxeiner, S.; Frank, M.; Zhang, Y.; Schuessler, R.B.; Smith, T.W.; Townsend, R.R.; Rohrs, H.W.; et al. Residual Cx45 and its relationship to Cx43 in murine ventricular myocardium. Channels (Austin) 2011, 5, 489-499. [CrossRef] [PubMed]

130. Johnstone, S.R.; Ross, J.; Rizzo, M.J.; Straub, A.C.; Lampe, P.D.; Leitinger, N.; Isakson, B.E. Oxidized phospholipid species promote in vivo differential $\mathrm{Cx} 43$ phosphorylation and vascular smooth muscle cell proliferation. Am. J. Pathol. 2009, 175, 916-924. [CrossRef] [PubMed]

131. Johnstone, S.R.; Kroncke, B.M.; Straub, A.C.; Best, A.K.; Dunn, C.A.; Mitchell, L.A.; Peskova, Y.; Nakamoto, R.K.; Koval, M.; Lo, C.W.; et al. Mapk phosphorylation of connexin 43 promotes binding of cyclin e and smooth muscle cell proliferation. Circ. Res. 2012, 111, 201-211. [CrossRef] [PubMed]

132. Pelletier, R.M.; Akpovi, C.D.; Chen, L.; Kumar, N.M.; Vitale, M.L. Complementary expression and phosphorylation of Cx46 and Cx50 during development and following gene deletion in mouse and in normal and orchitic mink testes. Am. J. Physiol. Regul. Integr. Comp. Physiol. 2015, 309, R255-R276. [CrossRef] [PubMed]

133. Walter, W.J.; Zeilinger, C.; Bintig, W.; Kolb, H.A.; Ngezahayo, A. Phosphorylation in the C-terminus of the rat connexin46 ( $\mathrm{rCx} 46)$ and regulation of the conducting activity of the formed connexons. J. Bioenergy Biomembr. 2008, 40, 397-405. [CrossRef] [PubMed]

134. Liu, J.; Ek Vitorin, J.F.; Weintraub, S.T.; Gu, S.; Shi, Q.; Burt, J.M.; Jiang, J.X. Phosphorylation of connexin 50 by protein kinase a enhances gap junction and hemichannel function. J. Biol. Chem. 2011, 286, 16914-16928. [CrossRef] [PubMed]

135. May, D.; Tress, O.; Seifert, G.; Willecke, K. Connexin 47 protein phosphorylation and stability in oligodendrocytes depend on expression of connexin43 protein in astrocytes. J. Neurosci. 2013, 33, 7985-7996. [CrossRef] [PubMed] 
136. Traub, O.; Look, J.; Dermietzel, R.; Brummer, F.; Hulser, D.; Willecke, K. Comparative characterization of the 21-kD and 26-kD gap junction proteins in murine liver and cultured hepatocytes. J. Cell Biol. 1989, 108, 1039-1051. [CrossRef] [PubMed]

137. Elvira, M.; Díez, J.A.; Wang, K.K.; Villalobo, A. Phosphorylation of connexin-32 by protein kinase C prevents its proteolysis by mu-calpain and m-calpain. J. Biol. Chem. 1993, 268, 14294-14300. [PubMed]

138. Locke, D.; Koreen, I.V.; Harris, A.L. Isoelectric points and post-translational modifications of connexin26 and connexin32. FASEB J. 2006, 20, 1221-1223. [CrossRef] [PubMed]

139. Locke, D.; Bian, S.; Li, H.; Harris, A.L. Post-translational modifications of connexin 26 revealed by mass spectrometry. Biochem. J. 2009, 424, 385-398. [CrossRef] [PubMed]

140. Berthoud, V.M.; Beyer, E.C.; Kurata, W.E.; Lau, A.F.; Lampe, P.D. The gap-junction protein connexin 56 is phosphorylated in the intracellular loop and the carboxy-terminal region. Eur. J. Biochem. 1997, 244, 89-97. [CrossRef] [PubMed]

141. Ouyang, X.; Winbow, V.M.; Patel, L.S.; Burr, G.S.; Mitchell, C.K.; O’Brien, J. Protein kinase a mediates regulation of gap junctions containing connexin 35 through a complex pathway. Brain Res. Mol. Brain Res. 2005, 135, 1-11. [CrossRef] [PubMed]

142. Johnstone, S.; Isakson, B.; Locke, D. Biological and biophysical properties of vascular connexin channels. Int. Rev. Cell Mol. Biol. 2009, 278, 69-118. [CrossRef] [PubMed]

143. Solan, J.L.; Lampe, P.D. Connexin43 phosphorylation: Structural changes and biological effects. Biochem. J. 2009, 419, 261-272. [CrossRef] [PubMed]

144. Chen, V.C.; Gouw, J.W.; Naus, C.C.; Foster, L.J. Connexin multi-site phosphorylation: Mass spectrometry-based proteomics fills the gap. Biochim. Biophys. Acta 2013, 1828, 23-34. [CrossRef] [PubMed]

145. Sorgen, P.L.; Duffy, H.S.; Spray, D.C.; Delmar, M. Ph-dependent dimerization of the carboxyl terminal domain of cx43. Biophys. J. 2004, 87, 574-581. [CrossRef] [PubMed]

146. Sorgen, P.L.; Duffy, H.S.; Sahoo, P.; Coombs, W.; Delmar, M.; Spray, D.C. Structural changes in the carboxyl terminus of the gap junction protein connexin43 indicates signaling between binding domains for c-Src and zonula occludens-1. J. Biol. Chem. 2004, 279, 54695-54701. [CrossRef] [PubMed]

147. Bouvier, D.; Kieken, F.; Kellezi, A.; Sorgen, P.L. Structural changes in the carboxyl terminus of the gap junction protein connexin 40 caused by the interaction with c-Src and zonula occludens-1. Cell Commun. Adhes. 2008, 15, 107-118. [CrossRef] [PubMed]

148. Solan, J.L.; Lampe, P.D. Spatio-temporal regulation of connexin43 phosphorylation and gap junction dynamics. Biochim. Biophys. Acta 2018, 1860, 83-90. [CrossRef] [PubMed]

149. Grosely, R.; Kopanic, J.L.; Nabors, S.; Kieken, F.; Spagnol, G.; Al-Mugotir, M.; Zach, S.; Sorgen, P.L. Effects of phosphorylation on the structure and backbone dynamics of the intrinsically disordered connexin 43 C-terminal domain. J. Biol. Chem. 2013, 288, 24857-24870. [CrossRef] [PubMed]

150. Sorgen, P.L.; Duffy, H.S.; Cahill, S.M.; Coombs, W.; Spray, D.C.; Delmar, M.; Girvin, M.E. Sequence-specific resonance assignment of the carboxyl terminal domain of connexin43. J. Biomol. NMR 2002, 23, 245-246. [CrossRef] [PubMed]

151. Shi, Q.; Banks, E.A.; Yu, X.S.; Gu, S.; Lauer, J.; Fields, G.B.; Jiang, J.X. Amino acid residue val362 plays a critical role in maintaining the structure of $\mathrm{C}$ terminus of connexin 50 and in lens epithelial-fiber differentiation. J. Biol. Chem. 2010, 285, 18415-18422. [CrossRef] [PubMed]

152. Kopanic, J.L.; Sorgen, P.L. Chemical shift assignments of the connexin 45 carboxyl terminal domain: Monomer and dimer conformations. Biomol. NMR Assign. 2013, 7, 293-297. [CrossRef] [PubMed]

153. Kopanic, J.L.; Al-mugotir, M.H.; Kieken, F.; Zach, S.; Trease, A.J.; Sorgen, P.L. Characterization of the connexin 45 carboxyl-terminal domain structure and interactions with molecular partners. Biophys. J. 2014, 106, 2184-2195. [CrossRef] [PubMed]

154. Kyle, J.W.; Berthoud, V.M.; Kurutz, J.; Minogue, P.J.; Greenspan, M.; Hanck, D.A.; Beyer, E.C. The $n$ terminus of connexin37 contains an $\alpha$-helix that is required for channel function. J. Biol. Chem. 2009, 284, 20418-20427. [CrossRef] [PubMed]

155. Bouvier, D.; Spagnol, G.; Chenavas, S.; Kieken, F.; Vitrac, H.; Brownell, S.; Kellezi, A.; Forge, V.; Sorgen, P.L. Characterization of the structure and intermolecular interactions between the connexin 40 and connexin 43 carboxyl-terminal and cytoplasmic loop domains. J. Biol. Chem. 2009, 284, 34257-34271. [CrossRef] [PubMed] 
156. Grosely, R.; Kieken, F.; Sorgen, P.L. ${ }^{1} \mathrm{~h},{ }^{13} \mathrm{c}$, and ${ }^{15} \mathrm{n}$ backbone resonance assignments of the connexin 43 carboxyl terminal domain attached to the 4 th transmembrane domain in detergent micelles. Biomol. NMR Assign. 2013, 7, 299-303. [CrossRef] [PubMed]

157. Sosinsky, G.E.; Solan, J.L.; Gaietta, G.M.; Ngan, L.; Lee, G.J.; Mackey, M.R.; Lampe, P.D. The C-terminus of connexin43 adopts different conformations in the golgi and gap junction as detected with structure-specific antibodies. Biochem. J. 2007, 408, 375-385. [CrossRef] [PubMed]

158. Grosely, R.; Kieken, F.; Sorgen, P.L. Optimizing the solution conditions to solve the structure of the connexin 43 carboxyl terminus attached to the 4(th) transmembrane domain in detergent micelles. Cell Commun. Adhes. 2010, 17, 23-33. [CrossRef] [PubMed]

159. Hirst-Jensen, B.J.; Sahoo, P.; Kieken, F.; Delmar, M.; Sorgen, P.L. Characterization of the PH-dependent interaction between the gap junction protein connexin 43 carboxyl terminus and cytoplasmic loop domains. J. Biol. Chem. 2007, 282, 5801-5813. [CrossRef] [PubMed]

160. Duffy, H.S.; Sorgen, P.L.; Girvin, M.E.; O’Donnell, P.; Coombs, W.; Taffet, S.M.; Delmar, M.; Spray, D.C. Ph-dependent intramolecular binding and structure involving Cx43 cytoplasmic domains. J. Biol. Chem. 2002, 277, 36706-36714. [CrossRef] [PubMed]

161. Cohen, P. The regulation of protein function by multisite phosphorylation-A 25 year update. Trends Biochem. Sci. 2000, 25, 596-601. [CrossRef]

162. Axelsen, L.N.; Calloe, K.; Holstein-Rathlou, N.H.; Nielsen, M.S. Managing the complexity of communication: Regulation of gap junctions by post-translational modification. Front. Pharmacol. 2013, 4, 130. [CrossRef] [PubMed]

163. Ek-Vitorin, J.F.; Burt, J.M. Structural basis for the selective permeability of channels made of communicating junction proteins. Biochim. Biophys. Acta 2013, 1828, 51-68. [CrossRef] [PubMed]

164. Moreno, A.P. Connexin phosphorylation as a regulatory event linked to channel gating. Biochim. Biophys. Acta 2005, 1711, 164-171. [CrossRef] [PubMed]

165. Saez, J.C.; Nairn, A.C.; Czernik, A.J.; Spray, D.C.; Hertzberg, E.L.; Greengard, P.; Bennett, M.V. Phosphorylation of connexin 32, a hepatocyte gap-junction protein, by cAMP-dependent protein kinase, protein kinase $\mathrm{C}$ and $\mathrm{Ca}^{2+}$ /calmodulin-dependent protein kinase II. Eur. J. Biochem. 1990, 192, $263-273$. [CrossRef] [PubMed]

166. Takeda, A.; Saheki, S.; Shimazu, T.; Takeuchi, N. Phosphorylation of the 27-kDa gap junction protein by protein kinase $\mathrm{c}$ in vitro and in rat hepatocytes. J. Biochem. 1989, 106, 723-727. [CrossRef] [PubMed]

167. Diez, J.A.; Elvira, M.; Villalobo, A. The epidermal growth factor receptor tyrosine kinase phosphorylates connexin32. Mol. Cell. Biochem. 1998, 187, 201-210. [CrossRef] [PubMed]

168. Kothmann, W.W.; Li, X.; Burr, G.S.; O'Brien, J. Connexin 35/36 is phosphorylated at regulatory sites in the retina. Vis. Neurosci. 2007, 24, 363-375. [CrossRef] [PubMed]

169. Li, H.; Chuang, A.Z.; O’Brien, J. Photoreceptor coupling is controlled by connexin 35 phosphorylation in zebrafish retina. J. Neurosci. 2009, 29, 15178-15186. [CrossRef] [PubMed]

170. Patel, L.S.; Mitchell, C.K.; Dubinsky, W.P.; O'Brien, J. Regulation of gap junction coupling through the neuronal connexin Cx35 by nitric oxide and cGMP. Cell Commun. Adhes. 2006, 13, 41-54. [CrossRef] [PubMed]

171. Li, H.; Chuang, A.Z.; O'Brien, J. Regulation of photoreceptor gap junction phosphorylation by adenosine in zebrafish retina. Vis. Neurosci. 2014, 31, 237-243. [CrossRef] [PubMed]

172. Kjenseth, A.; Fykerud, T.A.; Sirnes, S.; Bruun, J.; Yohannes, Z.; Kolberg, M.; Omori, Y.; Rivedal, E.; Leithe, E. The gap junction channel protein connexin 43 is covalently modified and regulated by sumoylation. J. Biol. Chem. 2012, 287, 15851-15861. [CrossRef] [PubMed]

173. Huang, R.Y.; Laing, J.G.; Kanter, E.M.; Berthoud, V.M.; Bao, M.; Rohrs, H.W.; Townsend, R.R.; Yamada, K.A. Identification of CaMKII phosphorylation sites in connexin43 by high-resolution mass spectrometry. J. Proteome Res. 2011, 10, 1098-1109. [CrossRef] [PubMed]

174. Cottrell, G.T.; Lin, R.; Warn-Cramer, B.J.; Lau, A.F.; Burt, J.M. Mechanism of v-Src- and mitogen-activated protein kinase-induced reduction of gap junction communication. Am. J. Physiol. Cell Physiol. 2003, 284, C511-C520. [CrossRef] [PubMed]

175. Lin, R.; Warn-Cramer, B.J.; Kurata, W.E.; Lau, A.F. v-Src phosphorylation of connexin 43 on Tyr247 and Tyr265 disrupts gap junctional communication. J. Cell Biol. 2001, 154, 815-827. [CrossRef] [PubMed] 
176. Giepmans, B.N.; Hengeveld, T.; Postma, F.R.; Moolenaar, W.H. Interaction of c-Src with gap junction protein connexin-43. Role in the regulation of cell-cell communication. J. Biol. Chem. 2001, 276, 8544-8549. [CrossRef] [PubMed]

177. Zhou, L.; Kasperek, E.M.; Nicholson, B.J. Dissection of the molecular basis of pp60(v-Src) induced gating of connexin 43 gap junction channels. J. Cell Biol. 1999, 144, 1033-1045. [CrossRef] [PubMed]

178. Swenson, K.I.; Piwnica-Worms, H.; McNamee, H.; Paul, D.L. Tyrosine phosphorylation of the gap junction protein connexin43 is required for the pp60v-Src-induced inhibition of communication. Cell Regul. 1990, 1, 989-1002. [CrossRef] [PubMed]

179. Lampe, P.D.; Kurata, W.E.; Warn-Cramer, B.J.; Lau, A.F. Formation of a distinct connexin 43 phosphoisoform in mitotic cells is dependent upon p34cdc2 kinase. J. Cell Sci. 1998, 111 Pt 6, 833-841. [PubMed]

180. Kanemitsu, M.Y.; Jiang, W.; Eckhart, W. Cdc2-mediated phosphorylation of the gap junction protein, connexin43, during mitosis. Cell Growth Differ. 1998, 9, 13-21. [PubMed]

181. Sirnes, S.; Kjenseth, A.; Leithe, E.; Rivedal, E. Interplay between pkc and the map kinase pathway in connexin43 phosphorylation and inhibition of gap junction intercellular communication. Biochem. Biophys. Res. Commun. 2009, 382, 41-45. [CrossRef] [PubMed]

182. Doble, B.W.; Dang, X.; Ping, P.; Fandrich, R.R.; Nickel, B.E.; Jin, Y.; Cattini, P.A.; Kardami, E. Phosphorylation of serine 262 in the gap junction protein connexin-43 regulates DNA synthesis in cell-cell contact forming cardiomyocytes. J. Cell Sci. 2004, 117, 507-514. [CrossRef] [PubMed]

183. Srisakuldee, W.; Jeyaraman, M.M.; Nickel, B.E.; Tanguy, S.; Jiang, Z.S.; Kardami, E. Phosphorylation of connexin-43 at serine 262 promotes a cardiac injury-resistant state. Cardiovasc. Res. 2009, 83, 672-681. [CrossRef] [PubMed]

184. Straub, A.C.; Billaud, M.; Johnstone, S.R.; Best, A.K.; Yemen, S.; Dwyer, S.T.; Looft-Wilson, R.; Lysiak, J.J.; Gaston, B.; Palmer, L.; et al. Compartmentalized connexin 43 S-nitrosylation/denitrosylation regulates heterocellular communication in the vessel wall. Arterioscler. Thromb. Vasc. Biol. 2011, 31, 399-407. [CrossRef] [PubMed]

185. Qi, G.J.; Chen, Q.; Chen, L.J.; Shu, Y.; Bu, L.L.; Shao, X.Y.; Zhang, P.; Jiao, F.J.; Shi, J.; Tian, B. Phosphorylation of connexin 43 by cdk5 modulates neuronal migration during embryonic brain development. Mol. Neurobiol. 2016, 53, 2969-2982. [CrossRef] [PubMed]

186. Procida, K.; Jorgensen, L.; Schmitt, N.; Delmar, M.; Taffet, S.M.; Holstein-Rathlou, N.H.; Nielsen, M.S.; Braunstein, T.H. Phosphorylation of connexin 43 on serine 306 regulates electrical coupling. Heart Rhythm 2009, 6, 1632-1638. [CrossRef] [PubMed]

187. Hund, T.J.; Decker, K.F.; Kanter, E.; Mohler, P.J.; Boyden, P.A.; Schuessler, R.B.; Yamada, K.A.; Rudy, Y. Role of activated CaMKII in abnormal calcium homeostasis and $\mathrm{i}(\mathrm{na})$ remodeling after myocardial infarction: Insights from mathematical modeling. J. Mol. Cell. Cardiol. 2008, 45, 420-428. [CrossRef] [PubMed]

188. Cooper, C.D.; Lampe, P.D. Casein kinase 1 regulates connexin-43 gap junction assembly. J. Biol. Chem. 2002, 277, 44962-44968. [CrossRef] [PubMed]

189. Paulson, A.F.; Lampe, P.D.; Meyer, R.A.; TenBroek, E.; Atkinson, M.M.; Walseth, T.F.; Johnson, R.G. Cyclic $\mathrm{AMP}$ and LDL trigger a rapid enhancement in gap junction assembly through a stimulation of connexin trafficking. J. Cell Sci. 2000, 113 Pt 17, 3037-3049. [PubMed]

190. Darrow, B.J.; Fast, V.G.; Kleber, A.G.; Beyer, E.C.; Saffitz, J.E. Functional and structural assessment of intercellular communication. Increased conduction velocity and enhanced connexin expression in dibutyryl camp-treated cultured cardiac myocytes. Circ. Res. 1996, 79, 174-183. [CrossRef] [PubMed]

191. TenBroek, E.M.; Lampe, P.D.; Solan, J.L.; Reynhout, J.K.; Johnson, R.G. Ser364 of connexin43 and the upregulation of gap junction assembly by camp. J. Cell Biol. 2001, 155, 1307-1318. [CrossRef] [PubMed]

192. Axelsen, L.N.; Stahlhut, M.; Mohammed, S.; Larsen, B.D.; Nielsen, M.S.; Holstein-Rathlou, N.H.; Andersen, S.; Jensen, O.N.; Hennan, J.K.; Kjolbye, A.L. Identification of ischemia-regulated phosphorylation sites in connexin43: A possible target for the antiarrhythmic peptide analogue rotigaptide (ZP123). J. Mol. Cell. Cardiol. 2006, 40, 790-798. [CrossRef] [PubMed]

193. Shah, M.M.; Martinez, A.M.; Fletcher, W.H. The connexin43 gap junction protein is phosphorylated by protein kinase a and protein kinase c: In vivo and in vitro studies. Mol. Cell. Biochem. 2002, 238, 57-68. [CrossRef] [PubMed]

194. Yogo, K.; Ogawa, T.; Akiyama, M.; Ishida, N.; Takeya, T. Identification and functional analysis of novel phosphorylation sites in Cx43 in rat primary granulosa cells. FEBS Lett. 2002, 531, 132-136. [CrossRef] 
195. Zou, J.; Yue, X.Y.; Zheng, S.C.; Zhang, G.; Chang, H.; Liao, Y.C.; Zhang, Y.; Xue, M.Q.; Qi, Z. Cholesterol modulates function of connexin 43 gap junction channel via PKC pathway in H9c2 cells. Biochim. Biophys. Acta 2014, 1838, 2019-2025. [CrossRef] [PubMed]

196. Ek-Vitorin, J.F.; King, T.J.; Heyman, N.S.; Lampe, P.D.; Burt, J.M. Selectivity of connexin 43 channels is regulated through protein kinase C-dependent phosphorylation. Circ. Res. 2006, 98, 1498-1505. [CrossRef] [PubMed]

197. Xie, Y.; Liu, S.; Hu, S.; Wei, Y. Cardiomyopathy-associated gene 1-sensitive PKC-dependent connexin 43 expression and phosphorylation in left ventricular noncompaction cardiomyopathy. Cell. Physiol. Biochem. 2017, 44, 828-842. [CrossRef] [PubMed]

198. Bao, X.; Altenberg, G.A.; Reuss, L. Mechanism of regulation of the gap junction protein connexin 43 by protein kinase C-mediated phosphorylation. Am. J. Physiol. Cell Physiol. 2004, 286, C647-C654. [CrossRef] [PubMed]

199. Liao, C.K.; Cheng, H.H.; Wang, S.D.; Yeih, D.F.; Wang, S.M. Pkcvarepsilon mediates serine phosphorylation of connexin43 induced by lysophosphatidylcholine in neonatal rat cardiomyocytes. Toxicology 2013, 314, 11-21. [CrossRef] [PubMed]

200. Dunn, C.A.; Lampe, P.D. Injury-triggered akt phosphorylation of Cx43: A ZO-1-driven molecular switch that regulates gap junction size. J. Cell Sci. 2014, 127, 455-464. [CrossRef] [PubMed]

201. Park, D.J.; Wallick, C.J.; Martyn, K.D.; Lau, A.F.; Jin, C.; Warn-Cramer, B.J. Akt phosphorylates connexin 43 on ser373, a "mode-1" binding site for 14-3-3. Cell Commun. Adhes. 2007, 14, 211-226. [CrossRef] [PubMed]

202. Berthoud, V.M.; Westphale, E.M.; Grigoryeva, A.; Beyer, E.C. Pkc isoenzymes in the chicken lens and TPA-induced effects on intercellular communication. Investig. Ophthalmol. Vis. Sci. 2000, 41, 850-858.

203. Isakson, B.E. Localized expression of an Ins(1,4,5)P3 receptor at the myoendothelial junction selectively regulates heterocellular Ca2+ communication. J. Cell Sci. 2008, 121, 3664-3673. [CrossRef] [PubMed]

204. Isakson, B.E.; Ramos, S.I.; Duling, B.R. Ca2+ and inositol 1,4,5-trisphosphate-mediated signaling across the myoendothelial junction. Circ. Res. 2007, 100, 246-254. [CrossRef] [PubMed]

205. Straub, A.C.; Johnstone, S.R.; Heberlein, K.R.; Rizzo, M.J.; Best, A.K.; Boitano, S.; Isakson, B.E. Site-specific connexin phosphorylation is associated with reduced heterocellular communication between smooth muscle and endothelium. J. Vasc. Res. 2010, 47, 277-286. [CrossRef] [PubMed]

206. Revel, J.P.; Karnovsky, M.J. Hexagonal array of subunits in intercellular junctions of the mouse heart and liver. J. Cell Biol. 1967, 33, C7-C12. [CrossRef] [PubMed]

207. Solan, J.L.; Marquez-Rosado, L.; Sorgen, P.L.; Thornton, P.J.; Gafken, P.R.; Lampe, P.D. Phosphorylation at s365 is a gatekeeper event that changes the structure of Cx43 and prevents down-regulation by PKC. J. Cell Biol. 2007, 179, 1301-1309. [CrossRef] [PubMed]

208. Lampe, P.D.; Cooper, C.D.; King, T.J.; Burt, J.M. Analysis of connexin 43 phosphorylated at s325, s328 and s330 in normoxic and ischemic heart. J. Cell Sci. 2006, 119, 3435-3442. [CrossRef] [PubMed]

209. Jabr, R.I.; Hatch, F.S.; Salvage, S.C.; Orlowski, A.; Lampe, P.D.; Fry, C.H. Regulation of gap junction conductance by calcineurin through Cx43 phosphorylation: Implications for action potential conduction. Pflugers Arch. 2016, 468, 1945-1955. [CrossRef] [PubMed]

210. Schulz, R.; Gres, P.; Skyschally, A.; Duschin, A.; Belosjorow, S.; Konietzka, I.; Heusch, G. Ischemic preconditioning preserves connexin 43 phosphorylation during sustained ischemia in pig hearts in vivo. FASEB J. 2003, 17, 1355-1357. [CrossRef] [PubMed]

211. Rhett, J.M.; Gourdie, R.G. The perinexus: A new feature of Cx43 gap junction organization. Heart Rhythm 2012, 9, 619-623. [CrossRef] [PubMed]

212. Palatinus, J.A.; O'Quinn, M.P.; Barker, R.J.; Harris, B.S.; Jourdan, J.; Gourdie, R.G. ZO-1 determines adherens and gap junction localization at intercalated disks. Am. J. Physiol. Heart Circ. Physiol. 2011, 300, H583-H594. [CrossRef] [PubMed]

213. Zhu, C.; Barker, R.J.; Hunter, A.W.; Zhang, Y.; Jourdan, J.; Gourdie, R.G. Quantitative analysis of ZO-1 colocalization with $\mathrm{C} \times 43$ gap junction plaques in cultures of rat neonatal cardiomyocytes. Microsc. Microanal. 2005, 11, 244-248. [CrossRef] [PubMed]

214. Hunter, A.W.; Barker, R.J.; Zhu, C.; Gourdie, R.G. Zonula occludens-1 alters connexin43 gap junction size and organization by influencing channel accretion. Mol. Biol. Cell 2005, 16, 5686-5698. [CrossRef] [PubMed] 
215. O'Quinn, M.P.; Palatinus, J.A.; Harris, B.S.; Hewett, K.W.; Gourdie, R.G. A peptide mimetic of the connexin43 carboxyl terminus reduces gap junction remodeling and induced arrhythmia following ventricular injury. Circ. Res. 2011, 108, 704-715. [CrossRef] [PubMed]

216. Schulz, R.; Görge, P.M.; Görbe, A.; Ferdinandy, P.; Lampe, P.D.; Leybaert, L. Connexin 43 is an emerging therapeutic target in ischemia/reperfusion injury, cardioprotection and neuroprotection. Pharmacol. Ther. 2015, 153, 90-106. [CrossRef] [PubMed]

217. Soder, B.L.; Propst, J.T.; Brooks, T.M.; Goodwin, R.L.; Friedman, H.I.; Yost, M.J.; Gourdie, R.G. The connexin43 carboxyl-terminal peptide act1 modulates the biological response to silicone implants. Plast. Reconstr. Surg. 2009, 123, 1440-1451. [CrossRef] [PubMed]

218. Su, G.Y.; Wang, J.; Xu, Z.X.; Qiao, X.J.; Zhong, J.Q.; Zhang, Y. Effects of rotigaptide (ZP123) on connexin43 remodeling in canine ventricular fibrillation. Mol. Med. Rep. 2015, 12, 5746-5752. [CrossRef] [PubMed]

219. Stahlhut, M.; Petersen, J.S.; Hennan, J.K.; Ramirez, M.T. The antiarrhythmic peptide rotigaptide (ZP123) increases connexin 43 protein expression in neonatal rat ventricular cardiomyocytes. Cell Commun. Adhes. 2006, 13, 21-27. [CrossRef] [PubMed]

220. Dhein, S.; Larsen, B.D.; Petersen, J.S.; Mohr, F.W. Effects of the new antiarrhythmic peptide ZP123 on epicardial activation and repolarization pattern. Cell Commun. Adhes. 2003, 10, 371-378. [CrossRef] [PubMed]

221. Xing, D.; Kjolbye, A.L.; Nielsen, M.S.; Petersen, J.S.; Harlow, K.W.; Holstein-Rathlou, N.H.; Martins, J.B. ZP123 increases gap junctional conductance and prevents reentrant ventricular tachycardia during myocardial ischemia in open chest dogs. J. Cardiovasc. Electrophysiol. 2003, 14, 510-520. [CrossRef] [PubMed]

222. Kjølbye, A.L.; Haugan, K.; Hennan, J.K.; Petersen, J.S. Pharmacological modulation of gap junction function with the novel compound rotigaptide: A promising new principle for prevention of arrhythmias. Basic Clin. Pharmacol. Toxicol. 2007, 101, 215-230. [CrossRef] [PubMed]

223. Skyschally, A.; Walter, B.; Schultz Hansen, R.; Heusch, G. The antiarrhythmic dipeptide ZP1609 (danegaptide) when given at reperfusion reduces myocardial infarct size in pigs. Naunyn-Schmiedeberg's Arch. Pharmacol. 2013, 386, 383-391. [CrossRef] [PubMed]

224. Cherepanova, O.A.; Pidkovka, N.A.; Sarmento, O.F.; Yoshida, T.; Gan, Q.; Adiguzel, E.; Bendeck, M.P.; Berliner, J.; Leitinger, N.; Owens, G.K. Oxidized phospholipids induce type viii collagen expression and vascular smooth muscle cell migration. Circ. Res. 2009, 104, 609-618. [CrossRef] [PubMed]

225. Kadl, A.; Meher, A.K.; Sharma, P.R.; Lee, M.Y.; Doran, A.C.; Johnstone, S.R.; Elliott, M.R.; Gruber, F.; Han, J.; Chen, W.S.; et al. Identification of a novel macrophage phenotype that develops in response to atherogenic phospholipids via nrf2. Circ. Res. 2010, 107, 737-746. [CrossRef] [PubMed]

226. Leitinger, N. Oxidized phospholipids as triggers of inflammation in atherosclerosis. Mol. Nutr. Food Res. 2005, 49, 1063-1071. [CrossRef] [PubMed]

227. Chatterjee, S.; Berliner, J.A.; Subbanagounder, G.G.; Bhunia, A.K.; Koh, S. Identification of a biologically active component in minimally oxidized low density lipoprotein (MM-LDL) responsible for aortic smooth muscle cell proliferation. Glycoconj. J. 2004, 20, 331-338. [CrossRef] [PubMed]

228. Good, M.E.; Nelson, T.K.; Simon, A.M.; Burt, J.M. A functional channel is necessary for growth suppression by Cx37. J. Cell Sci. 2011, 124, 2448-2456. [CrossRef] [PubMed]

229. Good, M.E.; Ek-Vitorín, J.F.; Burt, J.M. Extracellular loop cysteine mutant of Cx37 fails to suppress proliferation of rat insulinoma cells. J. Membr. Biol. 2012, 245, 369-380. [CrossRef] [PubMed]

230. Good, M.E.; Ek-Vitorin, J.F.; Burt, J.M. Structural determinants and proliferative consequences of connexin 37 hemichannel function in insulinoma cells. J. Biol. Chem. 2014, 289, 30379-30386. [CrossRef] [PubMed]

231. Traub, O.; Hertlein, B.; Kasper, M.; Eckert, R.; Krisciukaitis, A.; Hülser, D.; Willecke, K. Characterization of the gap junction protein connexin37 in murine endothelium, respiratory epithelium, and after transfection in human hela cells. Eur. J. Cell Biol. 1998, 77, 313-322. [CrossRef]

232. Morel, S.; Burnier, L.; Roatti, A.; Chassot, A.; Roth, I.; Sutter, E.; Galan, K.; Pfenniger, A.; Chanson, M.; Kwak, B.R. Unexpected role for the human Cx37 C1019T polymorphism in tumour cell proliferation. Carcinogenesis 2010, 31, 1922-1931. [CrossRef] [PubMed]

233. Larson, D.M.; Seul, K.H.; Berthoud, V.M.; Lau, A.F.; Sagar, G.D.; Beyer, E.C. Functional expression and biochemical characterization of an epitope-tagged connexin37. Mol. Cell. Biol. Res. Commun. 2000, 3, 115-121. [CrossRef] [PubMed] 
234. Vanhamme, L.; Rolin, S.; Szpirer, C. Inhibition of gap-junctional intercellular communication between epithelial cells transformed by the activated h-ras-1 oncogene. Exp. Cell Res. 1989, 180, 297-301. [CrossRef]

235. Azarnia, R.; Reddy, S.; Kmiecik, T.E.; Shalloway, D.; Loewenstein, W.R. The cellular SRC gene product regulates junctional cell-to-cell communication. Science 1988, 239, 398-401. [CrossRef] [PubMed]

236. Gonzalez-Sanchez, A.; Jaraiz-Rodriguez, M.; Dominguez-Prieto, M.; Herrero-Gonzalez, S.; Medina, J.M.; Tabernero, A. Connexin43 recruits PTEN and Csk to inhibit c-Src activity in glioma cells and astrocytes. Oncotarget 2016, 7, 49819-49833. [CrossRef] [PubMed]

237. Johnson, K.E.; Mitra, S.; Katoch, P.; Kelsey, L.S.; Johnson, K.R.; Mehta, P.P. Phosphorylation on ser-279 and ser-282 of connexin43 regulates endocytosis and gap junction assembly in pancreatic cancer cells. Mol. Biol. Cell 2013, 24, 715-733. [CrossRef] [PubMed]

238. Brissette, J.L.; Kumar, N.M.; Gilula, N.B.; Dotto, G.P. The tumor promoter 12-O-tetradecanoylphorbol13 -acetate and the ras oncogene modulate expression and phosphorylation of gap junction proteins. Mol. Cell. Biol. 1991, 11, 5364-5371. [CrossRef] [PubMed]

239. Oh, S.Y.; Grupen, C.G.; Murray, A.W. Phorbol ester induces phosphorylation and down-regulation of connexin 43 in wb cells. Biochim. Biophys. Acta 1991, 1094, 243-245. [CrossRef]

240. Asamoto, M.; Oyamada, M.; el Aoumari, A.; Gros, D.; Yamasaki, H. Molecular mechanisms of TPA-mediated inhibition of gap-junctional intercellular communication: Evidence for action on the assembly or function but not the expression of connexin 43 in rat liver epithelial cells. Mol. Carcinog. 1991, 4, 322-327. [CrossRef] [PubMed]

241. Ruch, R.J.; Trosko, J.E.; Madhukar, B.V. Inhibition of connexin43 gap junctional intercellular communication by tpa requires erk activation. J. Cell. Biochem. 2001, 83, 163-169. [CrossRef] [PubMed]

242. Ye, X.Y.; Jiang, Q.H.; Hong, T.; Zhang, Z.Y.; Yang, R.J.; Huang, J.Q.; Hu, K.; Peng, Y.P. Altered expression of connexin43 and phosphorylation connexin43 in glioma tumors. Int. J. Clin. Exp. Pathol. 2015, 8, 4296-4306. [PubMed]

243. Wu, J.F.; Ji, J.; Dong, S.Y.; Li, B.B.; Yu, M.L.; Wu, D.D.; Tao, L.; Tong, X.H. Gefitinib enhances oxaliplatin-induced apoptosis mediated by Src and PKC-modulated gap junction function. Oncol. Rep. 2016, 36, 3251-3258. [CrossRef] [PubMed]

244. Peterson-Roth, E.; Brdlik, C.M.; Glazer, P.M. Src-induced cisplatin resistance mediated by cell-to-cell communication. Cancer Res. 2009, 69, 3619-3624. [CrossRef] [PubMed]

245. Wong, P.; Tan, T.; Chan, C.; Laxton, V.; Chan, Y.W.; Liu, T.; Wong, W.T.; Tse, G. The role of connexins in wound healing and repair: Novel therapeutic approaches. Front. Physiol. 2016, 7, 596. [CrossRef] [PubMed]

246. Becker, D.L.; Thrasivoulou, C.; Phillips, A.R. Connexins in wound healing; perspectives in diabetic patients. Biochim. Biophys. Acta 2012, 1818, 2068-2075. [CrossRef] [PubMed]

247. Cogliati, B.; Vinken, M.; Silva, T.C.; Araújo, C.M.M.; Aloia, T.P.A.; Chaible, L.M.; Mori, C.M.C.; Dagli, M.L.Z. Connexin 43 deficiency accelerates skin wound healing and extracellular matrix remodeling in mice. J. Dermatol. Sci. 2015, 79, 50-56. [CrossRef] [PubMed]

248. Kim, M.O.; Ryu, J.M.; Suh, H.N.; Park, S.H.; Oh, Y.M.; Lee, S.H.; Han, H.J. Camp promotes cell migration through cell junctional complex dynamics and actin cytoskeleton remodeling: Implications in skin wound healing. Stem Cells Dev. 2015, 24, 2513-2524. [CrossRef] [PubMed]

249. Mehta, P.P.; Yamamoto, M.; Rose, B. Transcription of the gene for the gap junctional protein connexin 43 and expression of functional cell-to-cell channels are regulated by camp. Mol. Biol. Cell 1992, 3, 839-850. [CrossRef] [PubMed]

250. Richards, T.S.; Dunn, C.A.; Carter, W.G.; Usui, M.L.; Olerud, J.E.; Lampe, P.D. Protein kinase C spatially and temporally regulates gap junctional communication during human wound repair via phosphorylation of connexin43 on serine368. J. Cell Biol. 2004, 167, 555-562. [CrossRef] [PubMed]

251. Pollok, S.; Pfeiffer, A.C.; Lobmann, R.; Wright, C.S.; Moll, I.; Martin, P.E.; Brandner, J.M. Connexin 43 mimetic peptide gap27 reveals potential differences in the role of $\mathrm{Cx} 43$ in wound repair between diabetic and non-diabetic cells. J. Cell. Mol. Med. 2011, 15, 861-873. [CrossRef] [PubMed]

252. Solan, J.L.; Lampe, P.D. Kinase programs spatiotemporally regulate gap junction assembly and disassembly: Effects on wound repair. Semin. Cell Dev. Biol. 2016, 50, 40-48. [CrossRef] [PubMed]

253. Wang, C.M.; Lincoln, J.; Cook, J.E.; Becker, D.L. Abnormal connexin expression underlies delayed wound healing in diabetic skin. Diabetes 2007, 56, 2809-2817. [CrossRef] [PubMed] 
254. Brandner, J.M.; Houdek, P.; Hüsing, B.; Kaiser, C.; Moll, I. Connexins 26, 30, and 43: Differences among spontaneous, chronic, and accelerated human wound healing. J. Investig. Dermatol. 2004, 122, 1310-1320. [CrossRef] [PubMed]

255. Grek, C.L.; Montgomery, J.; Sharma, M.; Ravi, A.; Rajkumar, J.S.; Moyer, K.E.; Gourdie, R.G.; Ghatnekar, G.S. A multicenter randomized controlled trial evaluating a Cx43-mimetic peptide in cutaneous scarring. J. Investig. Dermatol. 2017, 137, 620-630. [CrossRef] [PubMed]

256. Stamler, J.S.; Simon, D.I.; Osborne, J.A.; Mullins, M.E.; Jaraki, O.; Michel, T.; Singel, D.J.; Loscalzo, J. S-nitrosylation of proteins with nitric oxide: Synthesis and characterization of biologically active compounds. Proc. Natl. Acad. Sci. USA 1992, 89, 444-448. [CrossRef] [PubMed]

257. Retamal, M.A.; García, I.E.; Pinto, B.I.; Pupo, A.; Báez, D.; Stehberg, J.; Del Rio, R.; González, C. Extracellular cysteine in connexins: Role as redox sensors. Front. Physiol. 2016, 7, 1. [CrossRef] [PubMed]

258. Contreras, J.E.; Sánchez, H.A.; Eugenin, E.A.; Speidel, D.; Theis, M.; Willecke, K.; Bukauskas, F.F.; Bennett, M.V.; Sáez, J.C. Metabolic inhibition induces opening of unapposed connexin 43 gap junction hemichannels and reduces gap junctional communication in cortical astrocytes in culture. Proc. Natl. Acad. Sci. USA 2002, 99, 495-500. [CrossRef] [PubMed]

259. Figueroa, X.F.; Lillo, M.A.; Gaete, P.S.; Riquelme, M.A.; Sáez, J.C. Diffusion of nitric oxide across cell membranes of the vascular wall requires specific connexin-based channels. Neuropharmacology 2013, 75, 471-478. [CrossRef] [PubMed]

260. Pogoda, K.; Füller, M.; Pohl, U.; Kameritsch, P. No, via its target Cx37, modulates calcium signal propagation selectively at myoendothelial gap junctions. Cell Commun. Signal. CCS 2014, 12, 33. [CrossRef] [PubMed]

261. Pogoda, K.; Mannell, H.; Blodow, S.; Schneider, H.; Schubert, K.M.; Qiu, J.; Schmidt, A.; Imhof, A.; Beck, H.; Tanase, L.I.; et al. No augments endothelial reactivity by reducing myoendothelial calcium signal spreading: A novel role for Cx37 (connexin 37) and the protein tyrosine phosphatase SHP-2. Arterioscler. Thromb. Vasc. Biol. 2017, 37, 2280-2290. [CrossRef] [PubMed]

262. Gareau, J.R.; Lima, C.D. The sumo pathway: Emerging mechanisms that shape specificity, conjugation and recognition. Nat. Rev. Mol. Cell Biol. 2010, 11, 861-871. [CrossRef] [PubMed]

263. Laird, D.W. Life cycle of connexins in health and disease. Biochem. J. 2006, 394, 527-543. [CrossRef] [PubMed]

264. Jiang, J.X.; Paul, D.L.; Goodenough, D.A. Posttranslational phosphorylation of lens fiber connexin46: A slow occurrence. Investig. Ophthalmol. Vis. Sci. 1993, 34, 3558-3565.

265. Beardslee, M.A.; Laing, J.G.; Beyer, E.C.; Saffitz, J.E. Rapid turnover of connexin43 in the adult rat heart. Circ. Res. 1998, 83, 629-635. [CrossRef] [PubMed]

266. Fallon, R.F.; Goodenough, D.A. Five-hour half-life of mouse liver gap-junction protein. J. Cell Biol. 1981, 90, 521-526. [CrossRef] [PubMed]

267. Norris, R.P.; Baena, V.; Terasaki, M. Localization of phosphorylated connexin 43 using serial section immunogold electron microscopy. J. Cell Sci. 2017, 130, 1333-1340. [CrossRef] [PubMed]

268. Boassa, D.; Solan, J.L.; Papas, A.; Thornton, P.; Lampe, P.D.; Sosinsky, G.E. Trafficking and recycling of the connexin43 gap junction protein during mitosis. Traffic 2010, 11, 1471-1486. [CrossRef] [PubMed]

269. Piehl, M.; Lehmann, C.; Gumpert, A.; Denizot, J.P.; Segretain, D.; Falk, M.M. Internalization of large double-membrane intercellular vesicles by a clathrin-dependent endocytic process. Mol. Biol. Cell 2007, 18, 337-347. [CrossRef] [PubMed]

270. Hunter, A.W.; Gourdie, R.G. The second pdz domain of zonula occludens-1 is dispensable for targeting to connexin 43 gap junctions. Cell Commun. Adhes. 2008, 15, 55-63. [CrossRef] [PubMed]

271. Chen, C.H.; Mayo, J.N.; Gourdie, R.G.; Johnstone, S.R.; Isakson, B.E.; Bearden, S.E. The connexin 43/ZO-1 complex regulates cerebral endothelial f-actin architecture and migration. Am. J. Physiol. Cell Physiol. 2015, 309, C600-C607. [CrossRef] [PubMed]

272. Leithe, E.; Sirnes, S.; Fykerud, T.; Kjenseth, A.; Rivedal, E. Endocytosis and post-endocytic sorting of connexins. Biochim. Biophys. Acta 2012, 1818, 1870-1879. [CrossRef] [PubMed]

273. Falk, M.M.; Fong, J.T.; Kells, R.M.; O’Laughlin, M.C.; Kowal, T.J.; Thevenin, A.F. Degradation of endocytosed gap junctions by autophagosomal and endo-/lysosomal pathways: A perspective. J. Membr. Biol. 2012, 245, 465-476. [CrossRef] [PubMed]

274. Leithe, E.; Rivedal, E. Ubiquitination of gap junction proteins. J. Membr. Biol. 2007, 217, 43-51. [CrossRef] [PubMed] 
275. Willis, M.S.; Townley-Tilson, W.H.; Kang, E.Y.; Homeister, J.W.; Patterson, C. Sent to destroy: The ubiquitin proteasome system regulates cell signaling and protein quality control in cardiovascular development and disease. Circ. Res. 2010, 106, 463-478. [CrossRef] [PubMed]

276. Voges, D.; Zwickl, P.; Baumeister, W. The 26s proteasome: A molecular machine designed for controlled proteolysis. Annu. Rev. Biochem. 1999, 68, 1015-1068. [CrossRef] [PubMed]

277. Bejarano, E.; Girao, H.; Yuste, A.; Patel, B.; Marques, C.; Spray, D.C.; Pereira, P.; Cuervo, A.M. Autophagy modulates dynamics of connexins at the plasma membrane in a ubiquitin-dependent manner. Mol. Biol. Cell 2012, 23, 2156-2169. [CrossRef] [PubMed]

278. Fong, J.T.; Kells, R.M.; Gumpert, A.M.; Marzillier, J.Y.; Davidson, M.W.; Falk, M.M. Internalized gap junctions are degraded by autophagy. Autophagy 2012, 8, 794-811. [CrossRef] [PubMed]

279. Lichtenstein, A.; Minogue, P.J.; Beyer, E.C.; Berthoud, V.M. Autophagy: A pathway that contributes to connexin degradation. J. Cell Sci. 2011, 124, 910-920. [CrossRef] [PubMed]

280. Bejarano, E.; Yuste, A.; Patel, B.; Stout, R.F., Jr.; Spray, D.C.; Cuervo, A.M. Connexins modulate autophagosome biogenesis. Nat. Cell Biol. 2014, 16, 401-414. [CrossRef] [PubMed]

281. Hesketh, G.G.; Shah, M.H.; Halperin, V.L.; Cooke, C.A.; Akar, F.G.; Yen, T.E.; Kass, D.A.; Machamer, C.E.; Van Eyk, J.E.; Tomaselli, G.F. Ultrastructure and regulation of lateralized connexin43 in the failing heart. Circ. Res. 2010, 106, 1153-1163. [CrossRef] [PubMed]

282. Leithe, E.; Rivedal, E. Ubiquitination and down-regulation of gap junction protein connexin- 43 in response to 12-O-tetradecanoylphorbol 13-acetate treatment. J. Biol. Chem. 2004, 279, 50089-50096. [CrossRef] [PubMed]

283. Zhu, X.; Ruan, Z.; Yang, X.; Chu, K.; Wu, H.; Li, Y.; Huang, Y. Connexin 31.1 degradation requires the clathrin-mediated autophagy in NSCLC cell h1299. J. Cell. Mol. Med. 2015, 19, 257-264. [CrossRef] [PubMed]

284. Catarino, S.; Ramalho, J.S.; Marques, C.; Pereira, P.; Girao, H. Ubiquitin-mediated internalization of connexin 43 is independent of the canonical endocytic tyrosine-sorting signal. Biochem. J. 2011, 437, 255-267. [CrossRef] [PubMed]

285. Girao, H.; Pereira, P. The proteasome regulates the interaction between Cx43 and ZO-1. J. Cell. Biochem. 2007, 102, 719-728. [CrossRef] [PubMed]

286. Dunn, C.A.; Su, V.; Lau, A.F.; Lampe, P.D. Activation of AKT, not connexin 43 protein ubiquitination, regulates gap junction stability. J. Biol. Chem. 2012, 287, 2600-2607. [CrossRef] [PubMed]

287. Totland, M.Z.; Bergsland, C.H.; Fykerud, T.A.; Knudsen, L.M.; Rasmussen, N.L.; Eide, P.W.; Yohannes, Z.; Sorensen, V.; Brech, A.; Lothe, R.A.; et al. The E3 ubiquitin ligase nedd4 induces endocytosis and lysosomal sorting of connexin 43 to promote loss of gap junctions. J. Cell Sci. 2017, 130, 2867-2882. [CrossRef] [PubMed]

288. Spagnol, G.; Kieken, F.; Kopanic, J.L.; Li, H.; Zach, S.; Stauch, K.L.; Grosely, R.; Sorgen, P.L. Structural studies of the NEDD4 WW domains and their selectivity for the connexin43 (Cx43) carboxyl terminus. J. Biol. Chem. 2016, 291, 7637-7650. [CrossRef] [PubMed]

289. Girao, H.; Catarino, S.; Pereira, P. Eps15 interacts with ubiquitinated Cx43 and mediates its internalization. Exp. Cell Res. 2009, 315, 3587-3597. [CrossRef] [PubMed]

290. Auth, T.; Schluter, S.; Urschel, S.; Kussmann, P.; Sonntag, S.; Hoher, T.; Kreuzberg, M.M.; Dobrowolski, R.; Willecke, K. The TSG101 protein binds to connexins and is involved in connexin degradation. Exp. Cell Res. 2009, 315, 1053-1062. [CrossRef] [PubMed]

291. Chen, V.C.; Kristensen, A.R.; Foster, L.J.; Naus, C.C. Association of connexin 43 with E3 ubiquitin ligase TRIM21 reveals a mechanism for gap junction phosphodegron control. J. Proteome Res. 2012, 11, 6134-6146. [CrossRef] [PubMed]

292. Basheer, W.A.; Harris, B.S.; Mentrup, H.L.; Abreha, M.; Thames, E.L.; Lea, J.B.; Swing, D.A.; Copeland, N.G.; Jenkins, N.A.; Price, R.L.; et al. Cardiomyocyte-specific overexpression of the ubiquitin ligase WWP1 contributes to reduction in connexin 43 and arrhythmogenesis. J. Mol. Cell. Cardiol. 2015, 88, 1-13. [CrossRef] [PubMed]

293. Fykerud, T.A.; Kjenseth, A.; Schink, K.O.; Sirnes, S.; Bruun, J.; Omori, Y.; Brech, A.; Rivedal, E.; Leithe, E. Smad ubiquitination regulatory factor-2 controls gap junction intercellular communication by modulating endocytosis and degradation of connexin43. J. Cell Sci. 2012, 125, 3966-3976. [CrossRef] [PubMed]

294. Fang, W.L.; Lai, S.Y.; Lai, W.A.; Lee, M.T.; Liao, C.F.; Ke, F.C.; Hwang, J.J. CRTC2 and NEDD4 ligase involvement in FSH and TGF $\beta 1$ upregulation of connexin43 gap junction. J. Mol. Endocrinol. 2015, 55, 263-275. [CrossRef] [PubMed] 
295. Colussi, C.; Gurtner, A.; Rosati, J.; Illi, B.; Ragone, G.; Piaggio, G.; Moggio, M.; Lamperti, C.; D’Angelo, G.; Clementi, E.; et al. Nitric oxide deficiency determines global chromatin changes in duchenne muscular dystrophy. FASEB J. 2009, 23, 2131-2141. [CrossRef] [PubMed]

296. Meraviglia, V.; Azzimato, V.; Colussi, C.; Florio, M.C.; Binda, A.; Panariti, A.; Qanud, K.; Suffredini, S.; Gennaccaro, L.; Miragoli, M.; et al. Acetylation mediates Cx43 reduction caused by electrical stimulation. J. Mol. Cell. Cardiol. 2015, 87, 54-64. [CrossRef] [PubMed]

297. Carette, D.; Gilleron, J.; Denizot, J.P.; Grant, K.; Pointis, G.; Segretain, D. New cellular mechanisms of gap junction degradation and recycling. Biol. Cell Auspices Eur. Cell Biol. Org. 2015, 107, 218-231. [CrossRef] [PubMed]

298. Koval, M. Pathways and control of connexin oligomerization. Trends Cell Biol. 2006, 16, 159-166. [CrossRef] [PubMed]

299. Koval, M.; Molina, S.A.; Burt, J.M. Mix and match: Investigating heteromeric and heterotypic gap junction channels in model systems and native tissues. FEBS Lett. 2014, 588, 1193-1204. [CrossRef] [PubMed]

300. Das, S.; Smith, T.D.; Sarma, J.D.; Ritzenthaler, J.D.; Maza, J.; Kaplan, B.E.; Cunningham, L.A.; Suaud, L.; Hubbard, M.J.; Rubenstein, R.C.; et al. ERP29 restricts connexin43 oligomerization in the endoplasmic reticulum. Mol. Biol. Cell 2009, 20, 2593-2604. [CrossRef] [PubMed]

301. Maza, J.; Das Sarma, J.; Koval, M. Defining a minimal motif required to prevent connexin oligomerization in the endoplasmic reticulum. J. Biol. Chem. 2005, 280, 21115-21121. [CrossRef] [PubMed]

302. Jara, O.; Acuna, R.; Garcia, I.E.; Maripillan, J.; Figueroa, V.; Saez, J.C.; Araya-Secchi, R.; Lagos, C.F.; Perez-Acle, T.; Berthoud, V.M.; et al. Critical role of the first transmembrane domain of Cx26 in regulating oligomerization and function. Mol. Biol. Cell 2012, 23, 3299-3311. [CrossRef] [PubMed]

303. Musil, L.S.; Goodenough, D.A. Multisubunit assembly of an integral plasma membrane channel protein, gap junction connexin43, occurs after exit from the ER. Cell 1993, 74, 1065-1077. [CrossRef]

304. Koval, M.; Harley, J.E.; Hick, E.; Steinberg, T.H. Connexin46 is retained as monomers in a trans-golgi compartment of osteoblastic cells. J. Cell Biol. 1997, 137, 847-857. [CrossRef] [PubMed]

305. Smith, T.D.; Mohankumar, A.; Minogue, P.J.; Beyer, E.C.; Berthoud, V.M.; Koval, M. Cytoplasmic amino acids within the membrane interface region influence connexin oligomerization. J. Membr. Biol. 2012, 245, 221-230. [CrossRef] [PubMed]

306. Lagree, V.; Brunschwig, K.; Lopez, P.; Gilula, N.B.; Richard, G.; Falk, M.M. Specific amino-acid residues in the N-terminus and TM3 implicated in channel function and oligomerization compatibility of connexin 43. J. Cell Sci. 2003, 116, 3189-3201. [CrossRef] [PubMed]

307. Molina, S.A.; Stauffer, B.; Moriarty, H.K.; Kim, A.H.; McCarty, N.A.; Koval, M. Junctional abnormalities in human airway epithelial cells expressing F508DEL CFTR. Am. J. Physiol. Lung Cell. Mol. Physiol. 2015, 309, L475-L487. [CrossRef] [PubMed]

308. Suaud, L.; Miller, K.; Alvey, L.; Yan, W.; Robay, A.; Kebler, C.; Kreindler, J.L.; Guttentag, S.; Hubbard, M.J.; Rubenstein, R.C. Erp29 regulates deltaf508 and wild-type cystic fibrosis transmembrane conductance regulator (CFTR) trafficking to the plasma membrane in cystic fibrosis (CF) and non-CF epithelial cells. J. Biol. Chem. 2011, 286, 21239-21253. [CrossRef] [PubMed]

309. Das Sarma, J.; Kaplan, B.E.; Willemsen, D.; Koval, M. Identification of Rab20 as a potential regulator of connexin43 trafficking. Cell Commun. Adhes. 2008, 15, 65-74. [CrossRef] [PubMed]

310. Asklund, T.; Appelskog, I.B.; Ammerpohl, O.; Ekstrom, T.J.; Almqvist, P.M. Histone deacetylase inhibitor 4-phenylbutyrate modulates glial fibrillary acidic protein and connexin 43 expression, and enhances gap-junction communication, in human glioblastoma cells. Eur. J Cancer 2004, 40, 1073-1081. [CrossRef] [PubMed]

311. Hattori, Y.; Fukushima, M.; Maitani, Y. Non-viral delivery of the connexin 43 gene with histone deacetylase inhibitor to human nasopharyngeal tumor cells enhances gene expression and inhibits in vivo tumor growth. Int. J. Oncol. 2007, 30, 1427-1439. [CrossRef] [PubMed]

312. Khan, Z.; Akhtar, M.; Asklund, T.; Juliusson, B.; Almqvist, P.M.; Ekstrom, T.J. Hdac inhibition amplifies gap junction communication in neural progenitors: Potential for cell-mediated enzyme prodrug therapy. Exp. Cell Res. 2007, 313, 2958-2967. [CrossRef] [PubMed]

313. Berthoud, V.M.; Minogue, P.J.; Guo, J.; Williamson, E.K.; Xu, X.; Ebihara, L.; Beyer, E.C. Loss of function and impaired degradation of a cataract-associated mutant connexin50. Eur. J. Cell Biol. 2003, 82, 209-221. [CrossRef] [PubMed] 
314. Kaufman, J.; Gordon, C.; Bergamaschi, R.; Wang, H.Z.; Cohen, I.S.; Valiunas, V.; Brink, P.R. The effects of the histone deacetylase inhibitor 4-phenylbutyrate on gap junction conductance and permeability. Front. Pharmacol. 2013, 4, 111. [CrossRef] [PubMed]

315. Berthoud, V.M.; Minogue, P.J.; Lambert, P.A.; Snabb, J.I.; Beyer, E.C. The cataract-linked mutant connexin50D47A causes endoplasmic reticulum stress in mouse lenses. J. Biol. Chem. 2016, 291, 17569-17578. [CrossRef] [PubMed]

316. Lichtenstein, A.; Gaietta, G.M.; Deerinck, T.J.; Crum, J.; Sosinsky, G.E.; Beyer, E.C.; Berthoud, V.M. The cytoplasmic accumulations of the cataract-associated mutant, connexin50P88S, are long-lived and form in the endoplasmic reticulum. Exp. Eye Res. 2009, 88, 600-609. [CrossRef] [PubMed]

317. Alapure, B.V.; Stull, J.K.; Firtina, Z.; Duncan, M.K. The unfolded protein response is activated in connexin 50 mutant mouse lenses. Exp. Eye Res. 2012, 102, 28-37. [CrossRef] [PubMed]

318. Tattersall, D.; Scott, C.A.; Gray, C.; Zicha, D.; Kelsell, D.P. Ekv mutant connexin 31 associated cell death is mediated by er stress. Hum. Mol. Genet. 2009, 18, 4734-4745. [CrossRef] [PubMed]

319. Xia, K.; Ma, H.; Xiong, H.; Pan, Q.; Huang, L.; Wang, D.; Zhang, Z. Trafficking abnormality and ER stress underlie functional deficiency of hearing impairment-associated connexin-31 mutants. Protein Cell 2010, 1, 935-943. [CrossRef] [PubMed]

320. Chen, S.; Zhang, D. Friend or foe: Endoplasmic reticulum protein 29 (ERP29) in epithelial cancer. FEBS Open Biol. 2015, 5, 91-98. [CrossRef] [PubMed]

321. Li, H.; Spagnol, G.; Pontifex, T.K.; Burt, J.M.; Sorgen, P.L. Chemical shift assignments of the connexin37 carboxyl terminal domain. Biomol. NMR Assign. 2017, 11, 137-141. [CrossRef] [PubMed]

322. Schlingmann, B.; Schadzek, P.; Hemmerling, F.; Schaarschmidt, F.; Heisterkamp, A.; Ngezahayo, A. The role of the C-terminus in functional expression and internalization of rat connexin46 (rcx46). J. Bioenergy Biomembr. 2013, 45, 59-70. [CrossRef] [PubMed]

323. Laing, J.G.; Koval, M.; Steinberg, T.H. Association with ZO-1 correlates with plasma membrane partitioning in truncated connexin 45 mutants. J. Membr. Biol. 2005, 207, 45-53. [CrossRef] [PubMed]

324. Trease, A.J.; Capuccino, J.M.V.; Contreras, J.; Harris, A.L.; Sorgen, P.L. Intramolecular signaling in a cardiac connexin: Role of cytoplasmic domain dimerization. J. Mol. Cell. Cardiol. 2017, 111, 69-80. [CrossRef] [PubMed]

325. Calero, G.; Kanemitsu, M.; Taffet, S.M.; Lau, A.F.; Delmar, M. A 17MER peptide interferes with acidification-induced uncoupling of connexin43. Circ. Res. 1998, 82, 929-935. [CrossRef] [PubMed]

326. Stergiopoulos, K.; Alvarado, J.L.; Mastroianni, M.; Ek-Vitorin, J.F.; Taffet, S.M.; Delmar, M. Hetero-domain interactions as a mechanism for the regulation of connexin channels. Circ. Res. 1999, 84, 1144-1155. [CrossRef] [PubMed]

327. Banerjee, D.; Das, S.; Molina, S.A.; Madgwick, D.; Katz, M.R.; Jena, S.; Bossmann, L.K.; Pal, D.; Takemoto, D.J. Investigation of the reciprocal relationship between the expression of two gap junction connexin proteins, connexin46 and connexin43. J. Biol. Chem. 2011, 286, 24519-24533. [CrossRef] [PubMed]

328. Basheer, W.; Shaw, R. The "tail" of connexin43: An unexpected journey from alternative translation to trafficking. Biochim. Biophys. Acta 2016, 1863, 1848-1856. [CrossRef] [PubMed]

329. Wellen, K.E.; Thompson, C.B. Cellular metabolic stress: Considering how cells respond to nutrient excess. Mol. Cell 2010, 40, 323-332. [CrossRef] [PubMed]

330. James, C.C.; Zeitz, M.J.; Calhoun, P.J.; Lamouille, S.; Smyth, J.W. Altered translation initiation of GJA1 limits gap junction formation during epithelial-mesenchymal transition. Mol. Biol. Cell 2018, 29, 797-808. [CrossRef]

331. Smyth, J.W.; Vogan, J.M.; Buch, P.J.; Zhang, S.S.; Fong, T.S.; Hong, T.T.; Shaw, R.M. Actin cytoskeleton rest stops regulate anterograde traffic of connexin 43 vesicles to the plasma membrane. Circ. Res. 2012, 110, 978-989. [CrossRef] [PubMed]

332. Shaw, R.M.; Fay, A.J.; Puthenveedu, M.A.; von Zastrow, M.; Jan, Y.N.; Jan, L.Y. Microtubule plus-end-tracking proteins target gap junctions directly from the cell interior to adherens junctions. Cell 2007, 128, 547-560. [CrossRef] [PubMed]

333. Giepmans, B.N.; Verlaan, I.; Hengeveld, T.; Janssen, H.; Calafat, J.; Falk, M.M.; Moolenaar, W.H. Gap junction protein connexin-43 interacts directly with microtubules. Curr. Biol. 2001, 11, 1364-1368. [CrossRef]

334. Yamane, Y.; Shiga, H.; Asou, H.; Ito, E. Gap junctional channel inhibition alters actin organization and calcium propagation in rat cultured astrocytes. Neuroscience 2002, 112, 593-603. [CrossRef] 
335. Theiss, C.; Meller, K. Microinjected anti-actin antibodies decrease gap junctional intercellular commmunication in cultured astrocytes. Exp. Cell Res. 2002, 281, 197-204. [CrossRef] [PubMed]

336. Cheng, C.; Nowak, R.B.; Gao, J.; Sun, X.; Biswas, S.K.; Lo, W.K.; Mathias, R.T.; Fowler, V.M. Lens ion homeostasis relies on the assembly and/or stability of large connexin 46 gap junction plaques on the broad sides of differentiating fiber cells. Am. J. Physiol. Cell Physiol. 2015, 308, C835-C847. [CrossRef] [PubMed]

337. Lauf, U.; Giepmans, B.N.; Lopez, P.; Braconnot, S.; Chen, S.C.; Falk, M.M. Dynamic trafficking and delivery of connexons to the plasma membrane and accretion to gap junctions in living cells. Proc. Natl. Acad. Sci. USA 2002, 99, 10446-10451. [CrossRef] [PubMed]

338. Rhett, J.M.; Jourdan, J.; Gourdie, R.G. Connexin 43 connexon to gap junction transition is regulated by zonula occludens-1. Mol. Biol. Cell 2011, 22, 1516-1528. [CrossRef] [PubMed]

339. Thevenin, A.F.; Margraf, R.A.; Fisher, C.G.; Kells-Andrews, R.M.; Falk, M.M. Phosphorylation regulates connexin43/zo-1 binding and release, an important step in gap junction turnover. Mol. Biol. Cell 2017, 28, 3595-3608. [CrossRef] [PubMed]

340. Van Itallie, C.M.; Fanning, A.S.; Bridges, A.; Anderson, J.M. Zo-1 stabilizes the tight junction solute barrier through coupling to the perijunctional cytoskeleton. Mol. Biol. Cell 2009, 20, 3930-3940. [CrossRef] [PubMed]

341. Fanning, A.S.; Van Itallie, C.M.; Anderson, J.M. Zonula occludens-1 and -2 regulate apical cell structure and the zonula adherens cytoskeleton in polarized epithelia. Mol. Biol. Cell 2012, 23, 577-590. [CrossRef] [PubMed]

342. Waxse, B.J.; Sengupta, P.; Hesketh, G.G.; Lippincott-Schwartz, J.; Buss, F. Myosin vi facilitates connexin 43 gap junction accretion. J. Cell Sci. 2017, 130, 827-840. [CrossRef] [PubMed]

343. Wang, H.Y.; Lin, Y.P.; Mitchell, C.K.; Ram, S.; O’Brien, J. Two-color fluorescent analysis of connexin 36 turnover: Relationship to functional plasticity. J. Cell Sci. 2015, 128, 3888-3897. [CrossRef] [PubMed]

344. Windoffer, R.; Beile, B.; Leibold, A.; Thomas, S.; Wilhelm, U.; Leube, R.E. Visualization of gap junction mobility in living cells. Cell Tissue Res. 2000, 299, 347-362. [CrossRef] [PubMed]

345. Wang, Y. Two-Color Fluorescent Analysis of Connexin 36 Turnover-Relationship to Functional plasticity. Ph.D. Dissertation, University of Texas, Houston, UT, USA, May 2015. GSBS Dissertations and Theses (Open Access).

346. Stahley, S.N.; Saito, M.; Faundez, V.; Koval, M.; Mattheyses, A.L.; Kowalczyk, A.P. Desmosome assembly and disassembly are membrane raft-dependent. PLoS ONE 2014, 9, e87809. [CrossRef] [PubMed]

347. Jennings, J.M.; Tucker, D.K.; Kottke, M.D.; Saito, M.; Delva, E.; Hanakawa, Y.; Amagai, M.; Kowalczyk, A.P. Desmosome disassembly in response to pemphigus vulgaris igg occurs in distinct phases and can be reversed by expression of exogenous DSG3. J. Investig. Dermatol. 2011, 131, 706-718. [CrossRef] [PubMed]

348. Schlingmann, B.; Overgaard, C.E.; Molina, S.A.; Lynn, K.S.; Mitchell, L.A.; Dorsainvil White, S.; Mattheyses, A.L.; Guidot, D.M.; Capaldo, C.T.; Koval, M. Regulation of claudin/zonula occludens-1 complexes by hetero-claudin interactions. Nat. Commun. 2016, 7, 12276. [CrossRef] [PubMed]

349. Ward, C.; Schlingmann, B.; Stecenko, A.A.; Guidot, D.M.; Koval, M. Nf-kb inhibitors impair lung epithelial tight junctions in the absence of inflammation. Tissue Barriers 2015, 3, e982424. [CrossRef] [PubMed]

350. Overgaard, C.E.; Schlingmann, B.; Dorsainvil White, S.; Ward, C.; Fan, X.; Swarnakar, S.; Brown, L.A.; Guidot, D.M.; Koval, M. The relative balance of GM-CSF and tgfbeta1 regulates lung epithelial barrier function. Am. J. Physiol. Lung Cell. Mol. Physiol. 2015, 308, L1212-L1223. [CrossRef] [PubMed]

351. Lafemina, M.J.; Rokkam, D.; Chandrasena, A.; Pan, J.; Bajaj, A.; Johnson, M.; Frank, J.A. Keratinocyte growth factor enhances barrier function without altering claudin expression in primary alveolar epithelial cells. Am. J. Physiol. Lung Cell. Mol. Physiol. 2010, 299, L724-L734. [CrossRef] [PubMed]

(C) 2018 by the authors. Licensee MDPI, Basel, Switzerland. This article is an open access article distributed under the terms and conditions of the Creative Commons Attribution (CC BY) license (http://creativecommons.org/licenses/by/4.0/). 